\title{
Petrophysical Evaluation and Potential Capability of Hydrocarbon Generation of Jurassic and Cretaceous Source Rocks in Shoushan Basin, North Western Desert, Egypt
}

\author{
Moataz Khairy Barakat \\ Geology Department, Faculty of Science, Tanta University, Tanta, 31527, Egypt
}

\begin{abstract}
The Shoushan Basin is an important hydrocarbon province in the northern Western Desert, Egypt. The present study deals with petrophysical evaluation, the identification of the potential and generating capability of hydrocarbon generation of Jurassic and Cretaceous formations in Shoushan Basin were investigated by studying the composite logs for five wells. Jurassic units include; Ras Qattara, Khatatba and Masajid formations. Jurassic formations are not recorded in the investigated wells except at TUT-21 well. Cretaceous units are represented by Alam El Bueib, Kharita and Abu Roash formations. The Alam El-Bueib Formation can be considered as an important reservoir rock in the Shoushan Basin, which is composed mainly of thick massive, argillaceous and calcareous sandstone with some shale and carbonate interbeds. The studied Alam El-Bueib Formation reservoirs include three main units; AEB-1, AEB-3A, 3D and 3E) subunits. Total organic carbon and Rock-Eval pyrolysis for 90 rock samples and geochemical model were used to determine the source rock characteristics and petroleum generative potentials of prospective source rocks, including quantity, type of organic matter, and their thermal maturity level. The results were then incorporated into basin modeling in order to improve our understanding of burial/ thermal histories and hydrocarbon generation and extraction from Jurassic-Cretaceous source rocks. Ras Qattara and Masajid formations have poor to fair generation potential while, Yakout and Khatatba formations have poor to excellent generation potential. Vitrinite reflectance values indicate that Ras Qatara, Yakout and Khatatba formations source rocks are mature and lie within oil generation stage. The organic richness of the Cretaceous formations varies from poor to excellent. The Cretaceous source rocks contain type IV kerogen and it indicates that the Cretaceous formations have very little gas potential and will not yield oil in any maturation stage. Vitrinite reflectance values indicate that Alam El Bueib and Kharita source rocks are becoming mature and lie within the onset of the oil generation stage. The burial history modeling shows that Ras Qattara and Yakout formations lie within the main mature oil window. Khataba and Masajid formations lie within oil windows and Alam El-Bueib and Khrita Formations are still within the early stage of hydrocarbon generation. While the Abu Roash Formation lie within immature stage.
\end{abstract}

Keywords: Petrophysical Evaluation, hydrocarbon Generation, Source rock, Shoushan Basin, Western Desert

\section{Introduction}

The Western Desert of Egypt covers two thirds of Egypt. It is considered the main prolific hydrocarbon province in Egypt. Approximately $90 \%$ of the Western Desert's oil production comes from the northern basins including Matruh - Shoushan basins. $70 \%$ of the hydrocarbons are produced from Jurassic-Cretaceous sands [1\&2]. The study area for this paper lies in the Shoushan Basin in the northern Western Desert of Egypt focusing on TUT Oil field (Fig. 1). The TUT Oilfield, discovered in 1986, lies between latitudes $30^{\circ} 40^{\prime} 15^{\prime \prime}-30^{\circ}$ $46^{\circ} 03^{\prime \prime} \mathrm{N}$ and longitudes $26^{\circ} 57^{\prime} 18^{\prime \prime}-27^{\circ} 00^{\prime} 00^{\prime \prime} \mathrm{E}$. located $4-5 \mathrm{~km}$ north and northwest of Salam field at the northern edge of the major Safir-salam-TUT ridge at Khalda concession in the northwestern part of Western Desert.

The Shoushan Basin contains sediments of Jurassic and younger ages. The presence of possible source rocks in the Shoushan Basin occurs in the Jurassic, Cretaceous and Palaeozoic rock units [3, 4, 5, 6 \& 7]. The Jurassic organic-rich sediments of the Ras Qattara, Masajid, Yakout and Khatatba Formations are considered to be the most prolific oil and gas prone source rocks in the basin. The Middle Jurassic Khatatba Formation is an attractive petroleum exploration target which is composed mainly of sandstone inter bedded with coals and carboniferous shales.

While, in Cretaceous successions (Alam El Bueib, Kharita and Abu Roash) Formations are the main source rocks in the basin. The Lower Cretaceous Alam El Bueib source rock has organic matter characteristics of deposition in clay-rich deltaic environment with significant input of terrestrial organic matter [8].

The present study aims to integrate the available subsurface geological, geophysical and geochemical data to study the reservoir characterization and hydrocarbon generation of Jurassic and Cretaceous source rocks in TUT Oil field Shoushan Basin, North Western Desert, Egypt. 


\section{Geological Setting}

The geology of the northern part of the Western Desert has been investigated by many authors such as $[9,10,11,12,13,14,15 \& 16]$. The northern Western Desert consists of a number of sedimentary basins that received a thick succession of Mesozoic sediments [4].

The study area (Shushan Basin) is within the tectonic zone of Egypt that is termed the unstable [17]. Shushan Basin is trending northeast-southwest and bounded to the north by the Umbaraka platform and to the south by north Qattra Ridge. The Shushan basin is a major basin developed in the Late Jurassic and Early Cretaceous in response to the opening of the Neo-Tethys Ocean to the north and remained a depocenter during most of the Cretaceous time.

The Shoushan Basin, the largest of the coastal basins, is a half-graben system with a maximum thickness of Jurassic to Palaeogene sediments [9\&12]. Structures of the north western Desert including Shoushan Basin resulted primarily from vertical movement of basement blocks and consisted of draped over and/or faulted anticline features. Compressional anticlines are subordinate and probably derive from drag folding, related to lateral movement along basement faults. The structures in the north Western Desert, focusing on the Shoushan Basin, consist mainly of parallel, elongated, tilted fault blocks, that is, horst and half-graben structures, with associated erosion of the upthrown blocks (Fig. 2).

The stratigraphic section in the northern Western Desert (including Shoushan Basin) ranges in age from Paleozoic to Tertiary and is summarized in (Fig. 3). The stratigraphy can be divided into four unconformity-bound cycles as proposed by each terminated by a marine transgression [18]. The earliest cycle consists of Early Jurassic non-marine siliciclastics (Ras Qattara Formation) which rest unconformably on the Silurian basement and which are overlain by the mid-Jurassic Wadi Natrun and Khatatba Formations. The Khatatba Formation is composed mainly of shales and sandstones with coal seams and minor limestones which become more abundant northwards. These sediments are interpreted to have been deposited in a deltaic environment.

During the Late Callovian, shallow-marine carbonates of the Masajid Formation were deposited and represent the maximum Jurassic transgression. The Masajid Formation was either eroded from, or was not deposited on, parts of the north Qattara Ridge and Umbarka Platform although continuous marine sedimentation occurred in the Matrah sub-basin and the Sidi Birrani area.

A major unconformity separates the Masajid Formation from the overlying Alam El Bueib Formation at the base of the second cycle, whose basal interval is composed of Early Cretaceous shallow marine sandstones and carbonates (Units 6 and 5). These are followed by marine shale (Unit 4) and a succession of massive fluviatile sandstones (Unit 3: Neocomian). Individual sandbodies are separated by marine shales. The sands are overlain by the alternating sands, shales and shelfal carbonates of Units 2 and 1, culminating in the Alamein Dolomite associated with the Aptian transgression. The Dahab Shale marks the end of this cycle.

An unconformity separates the Dahab Shale from the Kharita Formation at the base of the third cycle, which extends from the Middle Albian to the latest Cretaceous. The continental and shoreline sandstones of the Kharita Formation are overlain by the shallowmarine and nearshore deposits of the Bahariya Formation (Early Cenomanian). A marked deepening of depositional conditions is indicated by the deposition of the Abu Roash "G" (Late Cenomanian).

Widespread transgression occurred during the Senonian with deposition of the Abu Roash "F" to "A" (predominantly carbonates). The unconformably overlying Khoman Chalk Formation was deposited in the northern Western Desert. The cycle is terminated by an unconformity above which lies the Eocene Apollonia Formation above which are the Dabaa and Moghra Formations (marine clastics) which are capped by the Marmarica Limestone [14].

\section{Material And Methodology}

1. Available data: The data were made available by Khalda Petroleum Company (KPC) and the Egyptian General Petroleum Corporation (EGPC). These data are: (1) Well-log data of five wells; TUT-01, TUT-03, TUT -11, TUT-21and TUT -79 (Fig. 1). The well logs include (gamma ray, caliper, resistivity, neutron, density, and sonic). (2) Geochemical analysis data of TUT-21well are used to evaluate the source rock.

2. Methodology:

(1) Reservoir petrophysics: The logs were used for the lithological interpretation of the formations and the $\log$ correlations in the study area. The well log evaluation has been achieved using Interactive Petrophysics software (IP) version 4.2.

(2) Geochemistry of source: The evaluation of the source rocks in the study area depends on the geochemical parameters including (TOC wt \%, S1, S2, HI and OI) and vitrinite reflectance (Ro \%) of TUT21 well.

(3) Basin modeling: The thermal history of the basin, the timing of hydrocarbon generation and expulsion were done. This is through the construction and interpretation of $1 \mathrm{D}$ basin models, based on well logs data 
derived lithological, petrophysical analysis and geochemical data. In the study area, the calibration data for the thermal models includes vitrinite reflectance and the temperature. Modelled vitrinite reflectance (calculated by Easy \%Ro (Sweeney and Burnham, 1990)) has been compared to measured data in order to optimize the thermal history model [19].

\section{IV.1. Petrophysical Evaluation \\ IV.1.1. Lithostratigraphic Cross Section:}

\section{Results And Discussions}

The constructed lithostratigraphic cross sections illustrate the change in lithologic characters or any break in the depositional continuity. These sections show the equivalency of stratigraphic units, and exhibit thickness variation. Borehole data from five composite logs are used to construct a correlation chart as shown in (Fig.1). The correlation chart passes through TUT -21, TUT -3, TUT -1, TUT-11 and TUT -79 wells (Fig. 4). The Alamein Dolomite Formation used as datum plane for correlation. The chart shows three main units, they are AEB-1, AEB-2 and AEB-3 arranged from top to base respectively. AEB-3 unit is subdivided into four subunits (A, D and E). AEB-3 unit is more thickness than the other units. AEB-3 consists mainly of sandstone, siltstone, especially in subunits A and E with subordinate intercalation of shale. Alam El Bueib-2 and Alam El Bueib-3D subunit are relatively less thickness than the other units. Meanwhile, AEB-1 unit comprises mainly of sandstone with intercalation of siltstone, shale at the top parts.

\section{IV.1.2. Determination of lithology from $M-N$ crossplots:}

Lithology interpretation with neutron, density, and sonic logs is facilitated by the use of M-N crossplots. This plot was first introduced by [20]. It combines the data of all three porosity logs to provide the lithology-dependent quantities, $\mathrm{M}$ and $\mathrm{N}$, which are essentially independent of primary porosity. Therefore a crossplot of these two quantities makes lithology characteristics be more apparent. $\mathrm{M}$ and $\mathrm{N}$ are defined as:

$$
\begin{aligned}
& \mathrm{M}=(\Delta \mathrm{tf}-\Delta \mathrm{t}) /(\rho \mathrm{b}-\rho \mathrm{bf}) \times 0.01 \\
& \mathrm{~N}=(\phi \mathrm{Nf}-\phi \mathrm{N}) /(\rho \mathrm{b}-\rho \mathrm{bf})
\end{aligned}
$$

Where; $\Delta t_{f}$ is interval transit time of the mud fluid, $\Delta t$ is sonic log reading, $\rho b$ is density log reading, $\rho b_{f}$ is density of mud fluid, $\phi \mathrm{N}_{\mathrm{f}}$ is neutron of mud fluid, and $\phi \mathrm{N}$ is neutron log reading.

Figure (5) shows the mineralogical composition of the Alam EL-Bueib-1 reservoir. The majority of points are scattered to fill the space between quartz and calcite regions although they tend to be close to quartz region than calcite one as shown TUT-11 well. This may reflect the presence of sandstone reservoir with some limestone lithology. Some points are scattered downwards due to shale effect and this effect may be the reason of shifting points near dolomite region TUT-21. Also, the effect of gas appears in shifting the scattered point in the upright corner of the diagram.

The M-N crossplots of Alam EL-Bueib-3A reservoir (Fig.6) illustrates the most points are scattered on and very close to sandstone line especially TUT- 11 well, while the rest points are plotted between sandstone and limestone. This indicates the presence of sandstone reservoir with some limestone streaks. Some points scattered toward dolomite line are attributed to dolomitic cement. The effect of gas appears in shifting the point in the upright corner of the diagram TUT-11 well.

From the M-N crossplots of Alam EL-Bueib-3D reservoir of the study area (Fig. 7), it is observed that, the majority of plotted points are scattered between limestone and dolomite line (TUT-3, TUT-21 wells) due to the effect of shale. The other points scattered between sandstone and limestone lines. This indicates the lithology of Alam EL-Bueib-3D is shale interbedded with sand channels nd small streaks of limestone. Some points (TUT-3 and TUT-11wells) are distorted upwardly due to the secondary porosity or gas effect.

Figure (8) shows the mineralogical composition of the Alam EL-Bueib-3E reservoir. The majority of points are scattered to fill the quartz region and the space in between quartz and calcite regions and they tend to be close to quartz region than calcite one. This suggests the presence of sandstone reservoir with some limestone streaks. Some points are scattered downwards due to shale effect. Also, the effect of gas is strongly observed as shifting of points upwardly, in addition to the effect of sulfer as shifting of some point (TUT-3well) downwardly.The analyzed of petrophysical parameters indicate that out of four units of the Alam EL-Bueib Formation in TUT Oil field, the AEB-1, AEB-3A, AEB-3D and AEB-3E are hydrocarbon-bearing.

\section{IV.1.3. Petrophysical evaluation:}

The reservoir parameters which derived from average calculations for the different log parameters are mapped. The mapping includes the four reservoirs (Alam El Bueib-1, 3A, 3D and 3E).

Alam El Bueib-1 Reservoir maps: The effective porosity value increases in the northeast and south directions, while it decreases at west and southeast directions (Fig.9a). The hydrocarbon saturation map (Fig.9b) shows that the hydrocarbon saturation increases in the northeast direction. It decreases in the southeast and northwest directions of the study area. The net growth map (Fig.9c) displays that the distribution increases to the 
northwest and center part of the study area. The Alam El Bueib-1 has minimum distribution, $0 \%$ in southeast and west directions. The northwest direction of AEB-1 reservoir is the most favorable part for accumulation and production.

Alam El Bueib-3A Reservoir maps: The effective porosity value increases in the southwest directions, while it decreases at west and southwest directions (Fig.10a). The hydrocarbon saturation increases in the north and center part of the study area, while it decreases in the southeast direction (Fig.10b). The net growth distribution map (Fig.10c) tells that net growth increases in the north and in the south directions of the study area, while it decreases in the southeast and west directions and in the center of the study area. A remarkable increasing in hydrocarbon saturation, effective porosity and net growth sand of Alam EL-Bueib-3A to the south direction of the study area.

Alam El Bueib-3D Reservoir maps: The effective porosity value increases in the central part of the study area. Meanwhile it decreases at east and southeast directions (Fig.11a). The hydrocarbon saturation map of Alam El Bueib-3D reservoir (Fig.11b) shows that the hydrocarbon saturation increases in the southwest, northwest and northeast directions. It decreases in the southeast directions of the study area. The net growth map (Fig.11c) shows that the distribution increases to the northeast and south directions in the study area. The Alam El Bueib-3D has minimum distribution, $0 \%$ in southeast direction. The maps show that the south and west direction is the best location to drill new wells.

Alam El Bueib-3E Reservoir maps: The effective porosity increases towards southwest, west, east and northeast directions, while it decreases from central part of the study area to northwest direction (Fig. 12a). The hydrocarbon saturation increases in the north and east directions of the study area, while it decreases in the southwest and south directions (Fig.12b). The net growth distribution map (Fig.12c) reveals that net growth increases in the north and south directions of the study area, while it decreases in the southwest, south, and southeast directions. The most important location for accumulation and production are north and northeast directions.

\section{IV.2. Geochemistry of Source Rocks}

\section{IV.2.1. Source rock characteristics:}

Ninety ditch samples from Tut-21 Well representing the Jurassic source rocks (Ras Qattara,Yakout, Khatatba and Masajid formations) as well as the Lower Cretaceous source rocks (Alam El-Bueib, and Kharita Formations) and Upper Cretaceous (Abu Roash Formation) were used in the source rock evaluation of the study area.

The potentiality and generating capability source rocks for oil generation is evaluated by measuring of total organic carbon (TOC), pyrolysis derived (S1, S2) potentiality (S1), generating source potential (S2) [21]. The generation potential (GP), is identified by using the sum of $\mathrm{S} 1+\mathrm{S} 2$ obtained from pyrolysis analysis. The type of hydrocarbons products (QI) such as oil and gas generated from a source rock by using the ratio of the values $\mathrm{S} 2$ and S3 derived from pyrolysis analysis. The quality index $(\mathrm{QI}=\mathrm{S} 2 / \mathrm{S} 3)$ is proportional to the amount of hydrogen in a source rock and is an indicator of the potential to generate oil and gas [22]. Rock-Eval temperature pyrolysis $\left(\mathrm{T}_{\max }\right)$, oxygen and hydrogen indices $(\mathrm{OI}, \mathrm{HI})$, production index $(\mathrm{PI})$ and vitrinite reflectance $\left(\mathrm{R}_{\mathrm{o}} \%\right)$ of the rock samples.

\section{Jurassic formations:}

Sixty six samples were analyzed from Ras Qattara, Yakout, Khatatba and Masajid formations in Tut$21 \mathrm{X}$ as shown in (Table-1). The studied samples are mainly shales and some silt stones. The total organic carbon content (TOC wt \%) ranges from 0.77 to $1.87 \mathrm{wt} \%$ in Ras Qattara Formation, 0.74 to 24.59 in Yakout Formation, 0.99 to 18.56 wt \% in Khatatba Formation and 0.64 - 2.08 in Masajid Formation respectively. Based on the above mentioned values and using the classification of [23]. Ras Qattara Formation is considered as fair to good source rock where Yakout and Masajid formations as fair to very good source rocks and Khatatba Formation as good to very good source rock respectively (Fig. 13).

Table-1: Rock-Eval pyrolysis and vitrinite reflectance data (min. and max. values) for Jurassic source rocks.

\begin{tabular}{|c|c|c|c|c|}
\hline Parameters & $\begin{array}{l}\text { Ras Qattara Formation } \\
\text { (min. - max.) }\end{array}$ & $\begin{array}{l}\text { Yakout Formation } \\
\text { (min. - max.) }\end{array}$ & $\begin{array}{l}\text { Khatatba Formation } \\
\text { (min. - max.) }\end{array}$ & $\begin{array}{l}\text { Masajid Formation } \\
\text { (min. - max.) }\end{array}$ \\
\hline Depth interval (ft) & $12965-13155$ & $12465-12785$ & $11545-12455$ & $11235-11510$ \\
\hline No of samples & 17 & 18 & 22 & 9 \\
\hline TOC (Wt.\%) & $0.77-1.87$ & $0.74-24.59$ & $0.99-18.56$ & $0.64-2.08$ \\
\hline $\mathrm{S} 1(\mathrm{mg} / \mathrm{g})$ & $0.05-0.12$ & $0.03-1.04$ & $0.05-0.83$ & $0.04-0.09$ \\
\hline $\mathrm{S} 2(\mathrm{mg} / \mathrm{g})$ & $0.32-1.02$ & $0.4-42.98$ & $0.74-36.71$ & $0.12-1.07$ \\
\hline $\mathrm{S} 3(\mathrm{mg} / \mathrm{g})$ & $0.76-3.78$ & $0.78-6.87$ & $0.55-2.38$ & $0.78-1.88$ \\
\hline $\mathrm{T} \max \left(\mathrm{C}^{\circ}\right)$ & $420-437$ & $442-449$ & $430-447$ & $415-432$ \\
\hline Ro (\%) & $\begin{array}{l}1.01-1.011 \\
(3 \text { values })\end{array}$ & $\begin{array}{l}0.94-1.08 \\
(3 \text { values })\end{array}$ & $\begin{array}{l}0.66-0.98 \\
(6 \text { values })\end{array}$ & $\begin{array}{c}\# \\
\text { (No values) }\end{array}$ \\
\hline
\end{tabular}


Petrophysical Evaluation and Potential Capability of Hydrocarbon Generation of Jurassic and ..

\begin{tabular}{|c|c|c|c|c|}
\hline PI & $0.08-.17$ & $0.01-0.09$ & $0.01-0.06$ & $0.08-0.27$ \\
\hline S1+S2 & $0.37-1.11$ & $0.43-43.53$ & $0.79-37.54$ & $0.16-1.16$ \\
\hline S2/S3 & $0.18-0.47$ & $0.11-34.94$ & $0.44-30.59$ & $0.15-0.58$ \\
\hline HI $(\mathrm{mg} / \mathrm{g})$ & $36-73$ & $54-175$ & $75-198$ & $19-51$ \\
\hline $\mathrm{OI}(\mathrm{mg} / \mathrm{g})$ & $87-402$ & $5-491$ & $6-179$ & $79-128$ \\
\hline
\end{tabular}

Where; TOC: Total Organic Carbon (weight percent of the whole rock); S1: Low hydrocarbons yield (mg hydrocarbons/g rock); S2: High hydrocarbons yield (mg hydrocarbons/g rock); S3: Releasing of organically bound $\mathrm{CO} 2$ over the temperature range $\left(300-550{ }^{\circ} \mathrm{C}\right)$; Tmax: Temperature at which maximum emission of high temperature (S2) hydrocarbons occurs $\left({ }^{\circ} \mathrm{C}\right)$; Ro $(\%)$ vitrinite reflectance; PI: Production index $(\mathrm{S} 1 / \mathrm{S} 1+\mathrm{S} 2)$; S1+S2: Generation Potential (GP). S2/S3: hydrocarbons products type or Quality Index (QI). HI: Hydrogen index (mg hydrocarbons/g TOC); OI: Oxygen index (mg CO2/g TOC).

The hydrocarbon potential of Jurassic source rocks is evaluated by rock eval pyrolysis. The plots of "S1" and "S2" values versus depth indicate that, Ras Qattara and Masajid formations have poor source potential, while Yakout and Khatatba formations are poor to very good source rocks (Figs. 14 and 15) [23\&24]. The generation potential (GP) is identified by the sum of S1 and S2 peaks obtained from pyrolysis analysis ranging from 0.16 in Masajid Formation to $43.53 \mathrm{mg} \mathrm{HC} / \mathrm{g}$ rock in Yakout Formation (Table-1). The data indicates that Ras Qattara and Masajid formations have poor to fair generation potential while Yakout and Khatatba formations have poor to excellent generation potential [25].

The hydrogen index (HI) and oxygen index (OI) values for Jurassic source rocks range from 5 to 491 $\mathrm{mg} / \mathrm{g}$ (Table -1). The relationship between the Hydrogen Index (HI) and Oxygen Index (OI) reflects that, Yakout and Khatatba formations contain type III and type II of kerogen where Ras Qattara and Masajid formations contain type IV kerogen (Fig. 16). Therefore, Ras Qattara and Masajid Formations have very little gas potential and will not yield oil in any maturation stage whereas Yakout and Khatatba formations are potential source rock for generating mixed oil and gas.

Figure 17 shows the relation between carbon content (\%TOC) and hydrogen index (HI) indicates that, Ras Qattara and Masajid formations are no source rocks and Yakout and Khatatba formations are poor to good source rocks [26]. The quality index (QI) and the type of hydrocarbons products such as oil and gas generated from a source rock is derived from pyrolysis analysis using the ratio of $\mathrm{S}_{2} / \mathrm{S}_{3}$. Peters, 1986 stated that a QI of less than 1 is indicative for a poor source rock, a QI ranging from 1-5 indicates gas prone, from 5 - 10 gas and oil prone and more than 10 oil prone source rocks respectively. Hence, Ras Qattara and Masajid formations are classified are poor source rocks while; Yakout and Khatatba formations are considered oil and gas prone (Table1).

The $\mathrm{T}_{\max }$ " values of Jurassic formations (Table-1) indicating that, the samples of Yakout and Khatatba lie within oil generation stage while most of Ras Qattara and Masajid formations samples lie within immature stage (Fig. 18). Vitrinite reflectance (Ro \%)values indicate that Ras Qatara, Yakout and Khatatba formations source rocks are mature and lie within oil generation stage (Fig. 19). On the other hand, the production index (PI) of Jurassic formations ranges from 0.01 to 0.17 revealing that the majority of samples lieing within immature stage except for two samples from Masajid Formation lying within oil generation stage (Fig. 20).

\section{Cretaceous formations:}

Twenty four samples were analyzed from Alam ElvBueib, Khrita and Abu Roash formations at Tut-21 well clarified in (Table-2). All studied samples are shales. The total organic carbon content (TOC wt \%) ranges from $0.5 \mathrm{wt} \%$ to $3.62 \mathrm{wt} \%$ reflecting that Cretaceous source rocks are classified fair to good source rocks (Fig. 21).

The studied samples are characterized by " $\mathrm{S}_{1}$ " values range from 0.01 to $0.13 \mathrm{mg} / \mathrm{g}$ and " $\mathrm{S}_{2}$ " values range from 0.24 to $4.04 \mathrm{mg} / \mathrm{g}$ (Table-2) reflecting mainly poor source rock potential (Figs. 22 and 23). The generation potential $\left(\mathrm{S}_{1}+\mathrm{S}_{2}\right)$ of this formation ranges from 0.18 to $11.18 \mathrm{mg} \mathrm{HC} / \mathrm{g}$ rock (Table-2) showing that the organic richness of this formation varies from poor to excellent.

Table-2: Rock-Eval pyrolysis and vitrinite reflectance data (min. and max. values) for Cretaceous source rocks

\begin{tabular}{|c|c|c|c|}
\hline Parameters & $\begin{array}{c}\text { Alam El Bueib Formation } \\
\text { (min. }- \text { max.) }\end{array}$ & $\begin{array}{c}\text { Khrita Formation } \\
(\text { min. }- \text { max. }\end{array}$ & $\begin{array}{c}\text { Abu Roash Formation } \\
\text { (min. }- \text { max. })\end{array}$ \\
\hline Depth interval (ft) & $8155-10855$ & $7050-7245$ & $5785-5895$ \\
\hline No of samples & 14 & 3 & $0.5-.71$ \\
\hline TOC $(\mathrm{Wt} . \%)$ & $0.54-3.62$ & $0.68-1.4$ & $0.01-0.04$ \\
\hline S1 (mg/g) & $0.03-0.13$ & $0.02-0.03$ & $0.24-0.59$ \\
\hline S2 (mg/g) & $0.28-4.04$ & $0.31-0.79$ & $0.26-0.33$ \\
\hline S3 (mg/g) & $0.82-1.93$ & $0.39-0.78$ & $423-428$ \\
\hline T max (C) & $425-433$ & $425-427$ & \# \\
\hline Ro $(\%)$ & $0.52-0.67$ & 0.62 & No values \\
\hline
\end{tabular}


Petrophysical Evaluation and Potential Capability of Hydrocarbon Generation of Jurassic and ..

\begin{tabular}{|c|c|c|c|}
\hline PI & $0.03-0.17$ & $0.04-0.06$ & $0.03-0.10$ \\
\hline $\mathrm{S} 1+\mathrm{S} 2$ & $0.31-4.16$ & $0.33-0.82$ & $0.25-0.61$ \\
\hline $\mathrm{S} 2 / \mathrm{S} 3$ & $0.20-4.16$ & $0.40-2.03$ & $0.92-2.23$ \\
\hline $\mathrm{HI}(\mathrm{mg} / \mathrm{g})$ & $50-112$ & $46-64$ & $48-96$ \\
\hline $\mathrm{OI}(\mathrm{mg} / \mathrm{g})$ & $27-276$ & $28-115$ & $37-62$ \\
\hline
\end{tabular}

Where; TOC: Total Organic Carbon (weight percent of the whole rock); S1: Low hydrocarbons yield (mg hydrocarbons/g rock); S2: High hydrocarbons yield (mg hydrocarbons/g rock); S3: Releasing of organically bound $\mathrm{CO} 2$ over the temperature range $\left(300-550{ }^{\circ} \mathrm{C}\right)$; Tmax: Temperature at which maximum emission of high temperature (S2) hydrocarbons occurs $\left({ }^{\circ} \mathrm{C}\right)$; Ro $(\%)$ vitrinite reflectance; PI: Production index $(\mathrm{S} 1 / \mathrm{S} 1+\mathrm{S} 2)$; S1+S2: Generation Potential (GP). S2/S3: hydrocarbons products type or Quality Index (QI). HI: Hydrogen index (mg hydrocarbons/g TOC); OI: Oxygen index (mg CO2/g TOC).

Table-2 shows the hydrogen index (HI) ranges from 46 to $112 \mathrm{mg} / \mathrm{g}$ and the oxygen index (OI) ranges from 28 to $276 \mathrm{mg} / \mathrm{g}$ (Fig. 24). These data show that the Cretaceous source rocks contain type IV kerogen and it indicates that the Cretaceous formations have very little gas potential and will not yield oil in any maturation stage. The relation between TOC and HI confirms that these formations are no source (Fig.25). The type of hydrocarbons products or quality index (QI) $\left(\mathrm{S}_{2} / \mathrm{S}_{3}\right)$ ranging from 0.20 to 4.16 (Table-2) indicates that, Alam El Bueib, Kharita and Abu Roash formations source rocks are mainly poor to gas prone source rocks.

The Cretaceous source rocks has " $\mathrm{T}_{\max }$ " values range from $423{ }^{\circ} \mathrm{C}$ to $433{ }^{\circ} \mathrm{C}$ indicating that the samples lie within immature stage (Fig.26) and $\mathrm{R}_{\mathrm{o}} \%$ values range from $0.52 \% .67 \%$ indicate that Alam El Bueib and Kharita source rocks are becoming mature and lie within the onset of the oil generation stage (Fig.27). On the other hand, the production index (PI) of these formations ranges from 0.03 at to 0.17 putting the samples within immature stage (Fig. 28).

\section{IV.2.2. Numerical basin modeling}

Basin modeling is widely used in studies of burial and thermal histories [27, 28, 29\&30]. The aim of the numerical modeling here is to reconstruct the thermal history and the timing of hydrocarbon generation of Jurassic and Cretaceous formations in the Shoushan Basin. The modeling inputs included the events (e.g., deposition, erosion, hiatus, or non-deposition); present-day and original thicknesses; lithology of strata; and present-day depth. The models were calibrated against both the present-day temperatures, and the measured reflectance profile by adjusting heat flow until a match is observed.

\section{$\underline{\text { Burial history }}$}

The burial (subsidence) and thermal histories are necessary in order to predict timing of hydrocarbon generation and expulsion. To describe the resulting models clearly, we review first the results of our reconstruction of the burial and thermal histories. The sedimentation rate can be estimated using the depositional age and thickness (the present thickness) for the formations, which are penetrated by the studied well (Fig.29). During the Jurassic (198-144 Ma), Ras Qattara, Yakout, Khatatba, and Masajid Formations, sedimentation was characterized by relatively low burial rates. Subsidence and sedimentation resumed in the Lower Cretaceous (144-104 Ma) the subsidence rate is increase. However, the Alam El-Bueib Formation during that time was not buried deeply, and the temperatures were too low for petroleum generation. The Alam El-Bueib Formation underwent continuous burial as the Late Cretaceous-Tertiary sediments accumulated, and the Alam El-Bueib source rock reached maximum burial depth during Middle Miocene. The Late Cretaceous (104-66 Ma), Abu Roash formation was characterized by higher burial rates. The overlying Tertiary was characterized by relatively low average subsidence rates.

\section{Thermal history and palaeo-temperature data}

Analysis of the tectonic evolution of the Shoushan Basin and the recent heat flow distribution were used for a qualitative reconstruction of the basin's thermal history. The thermal history of a sedimentary basin depends not only on the deposition and erosion history but also on the heat-flow evolution [31\&32]. In this study, analysis of the influence of the tectonic evolution in the basin on the heat flow distribution through time was made using PetroMod (2012.1) 1D modeling. The thermal history during the tectonic development was calibrated with vitrinite reflectance data from the Cretaceous and Jurassic sediments. The calibration curves for the studied wells are presented in Figure 30, which shows plots of vitrinite reflectance data and corrected bottom-hole temperature versus depths. A good match between measured (symbols) and calculated (lines) vitrinite reflectance values was generally achieved. The reconstruction of the thermal history of the basin is always simplified and is usually calibrated against profiles of maturity (e.g. vitrinite reflectance). In this $1 \mathrm{D}$ model, the heat flow values were estimated and calibrated using measured vitrinite reflectance (\%VRr) data. In TUT-21well, heat flow values range between 40 and $73 \mathrm{~mW} / \mathrm{m}^{2}$, which are used for numerical modeling in the study area [6\&33]. Different heat flows at the studied wells were required to achieve a good fit between 
corrected measured bottom-hole temperatures and calculated temperatures. However, these variations are not required to match the measured vitrinite reflectance values. Generally, the fit of the calculated maturity profile with the measured vitrinite reflectance (\%Ro) data supports the thermal maturity patterns resulting from maximum burial and normal heat flow similar to the modern-day values (Fig. 31).

\section{Timing of hydrocarbon generation}

In the present study, the burial history model of the different hydrocarbon bearing rock units in TUT-21 well was constructed to predict the maturity of the source rock, timing of hydrocarbon generation, expulsion and migration (Fig. 32).

The Ras Qattara Formation entered to the early mature oil stage of hydrocarbon generation during Early Cretaceous time at $105 \mathrm{Mybp}$ (million years before present). It reached to the main mature oil during Late Cretaceous at 88 Mybp and entered to the late mature oil during Eocene at 52 Mybp till present time. Yakout Formation reached to the early mature stage of hydrocarbon generation during Early Cretaceous time at 100 Mybp and reached to the main mature oil during Late Cretaceous at 85 Mybp and entered to the late mature oil during Oligocene at about 25 Mybp till Recent.

Khatatba Formation started to generate hydrocarbons during Late Cretaceous time at 90 Mybp as indicated by the thermal burial history model (Fig. 32). It reached to main mature during Late Cretaceous at 72 Mybp till present time. Khatatba Formation bears a mature source rock with good generating capability for oil.

Masajid Formation entered to the early stage of hydrocarbon generation at 88 Mybp (million years before present) during Early Cretaceous time. It reached to the oil window to during Late Cretaceous time at 68 Mybp till present time (Fig. 32). Meanwhile, Alam El-Bueib and Khrita formations reached to the early stage of hydrocarbon generation at 62 and 12 Mybp till present time respectively. While the Abu Roash Formation lie within immature stage (Fig. 32).

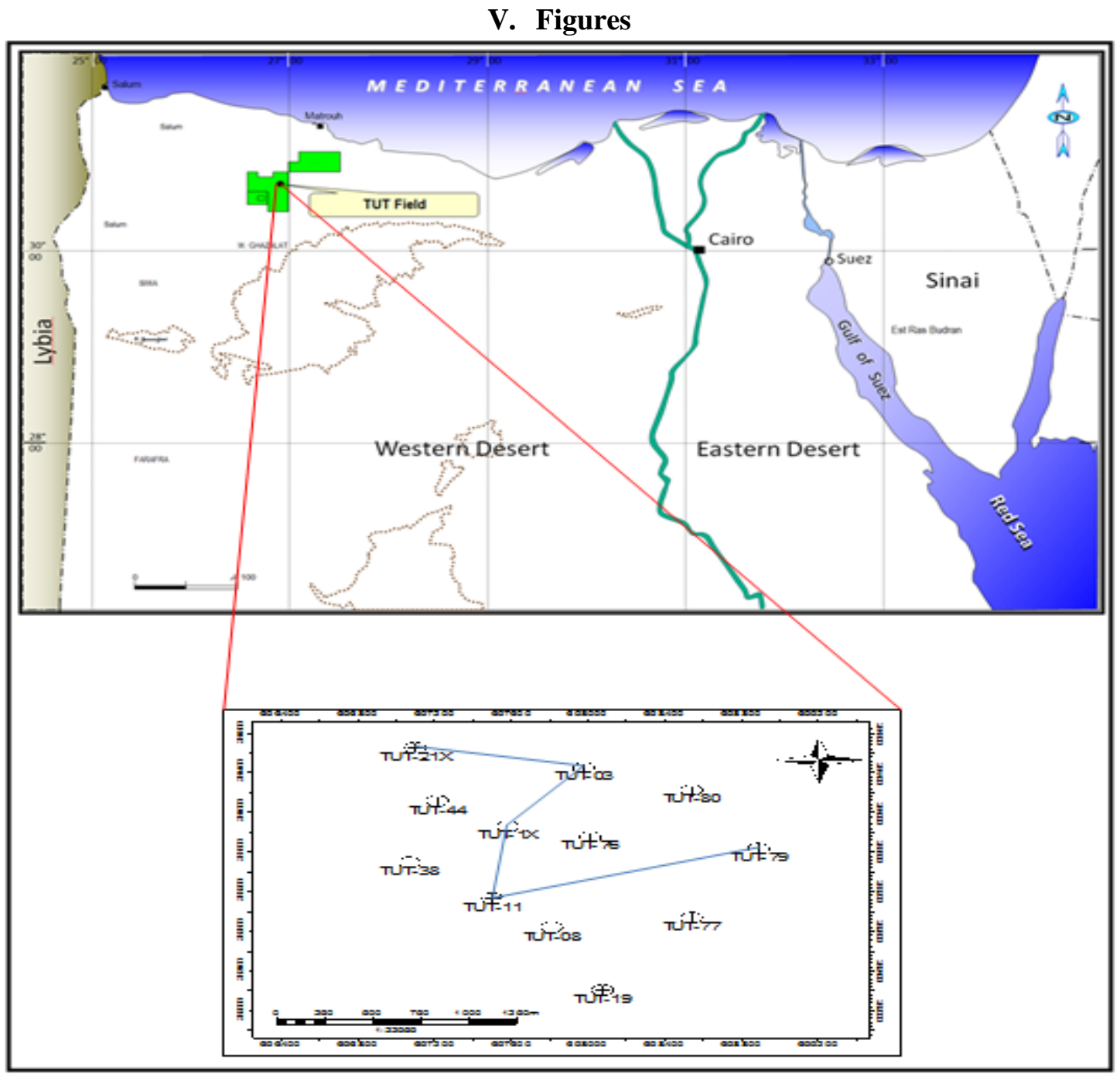

Fig. 1: Location map for the area of study. 

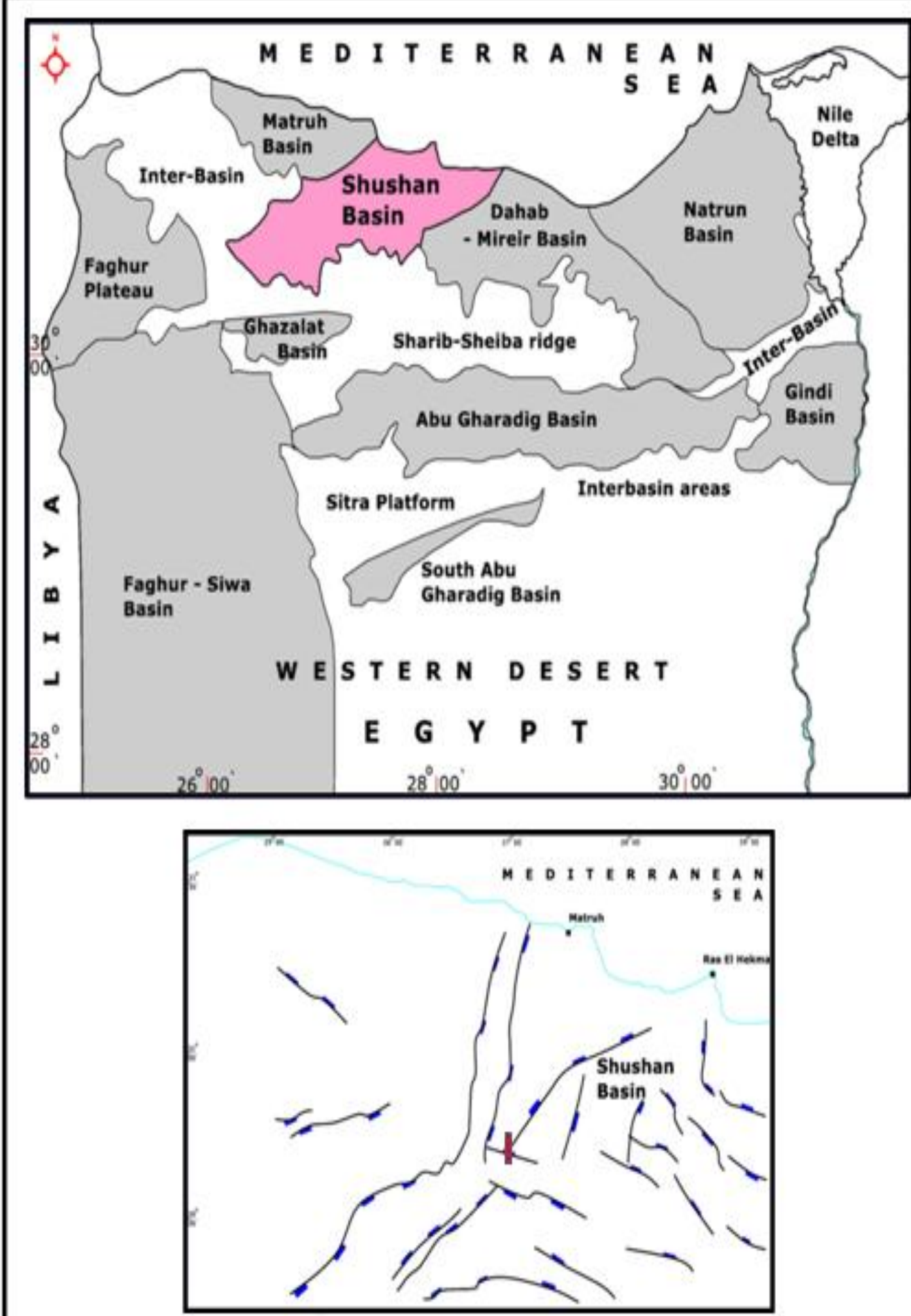

Fig.2: Location map of the Shushan Basin. The area enlarged given below shows the major Structural features and main faults in the Shushan Basin [33\&34]. 


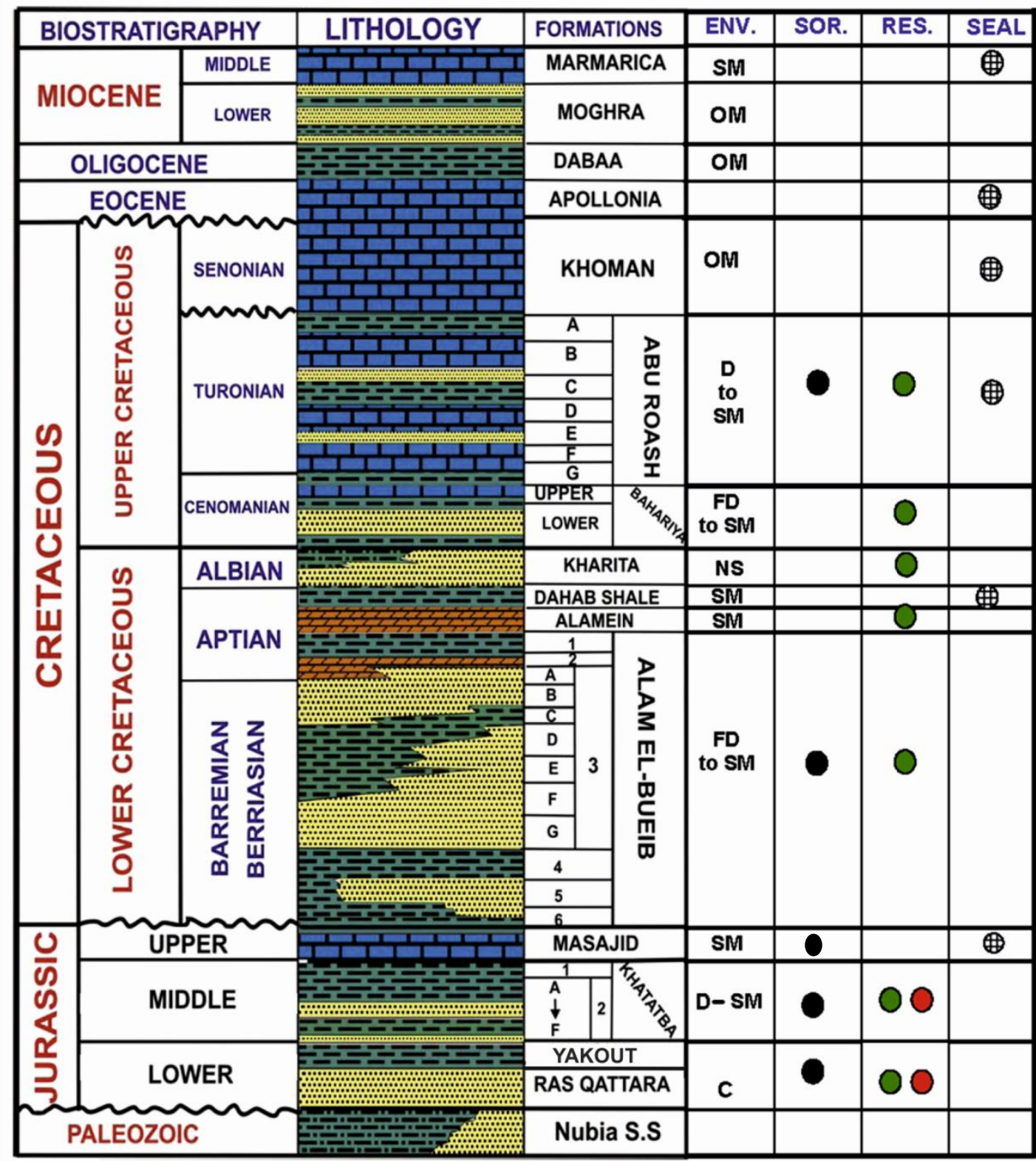

$\mathrm{SM}=$ Shallow Marine

$\mathrm{D}=$ Deltaic

$\mathrm{FD}=$ Fluvial Deltaic

RES $=$ Reservoir rock

= Source

丹 Seal
$\mathrm{OM}=$ Open Marine

$\mathrm{F}=$ Fluvial

ENV. $=$ Environment

0 = Reservoir / oil
NS $=$ Near Shore

$\mathrm{C}=$ Continental

SOR = Source rock

0 = Reservoir / gas

Fig. 3: Generalized stratigraphic sketch of north Western Desert [35\&36]. 


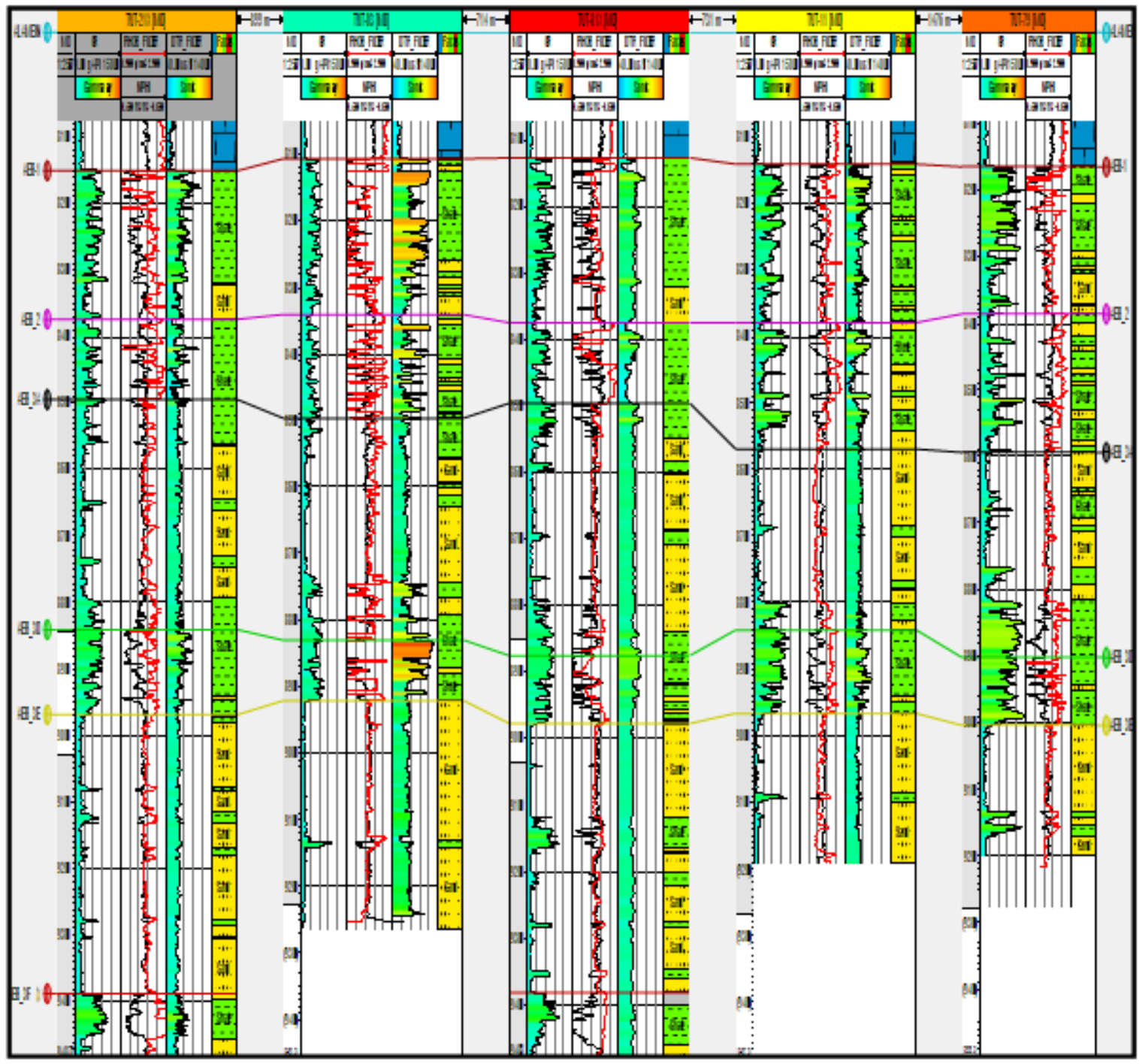

Fig. 4: Correlation chart passes through TUT -21, TUT -3, TUT -1, TUT-11 and TUT -79 wells.

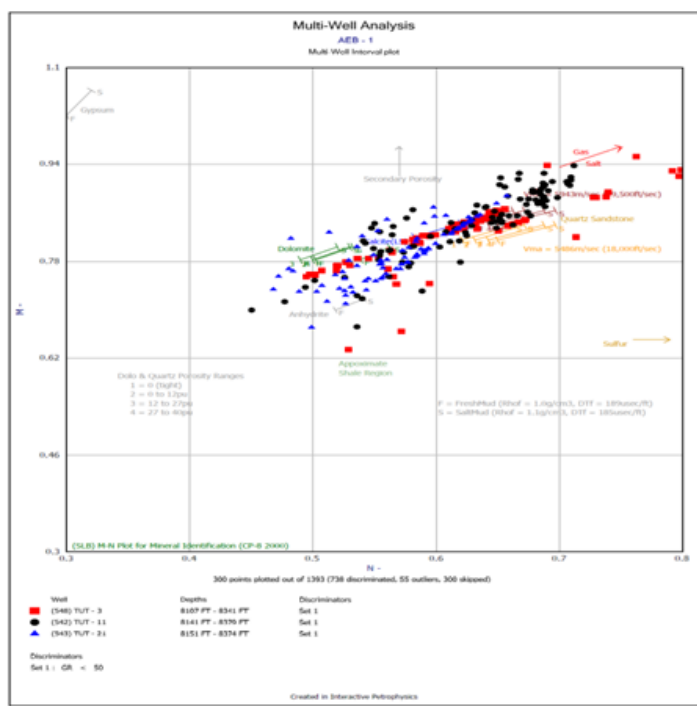

Fig.5: $\mathrm{M}$ - N crossplot of the AEB-1 reservoir.

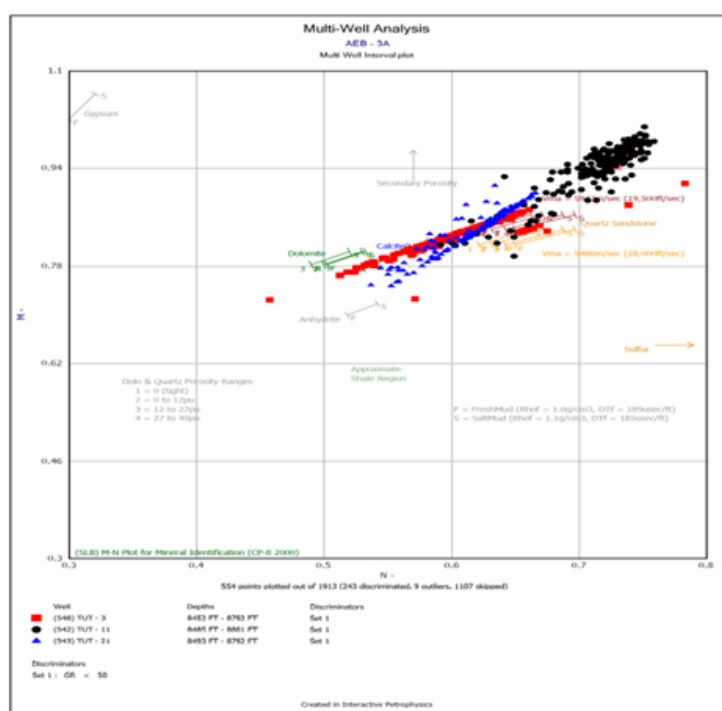

Fig.6: $\mathrm{M}$ - N crossplot of the AEB-3A reservoir. 
Petrophysical Evaluation and Potential Capability of Hydrocarbon Generation of Jurassic and ..

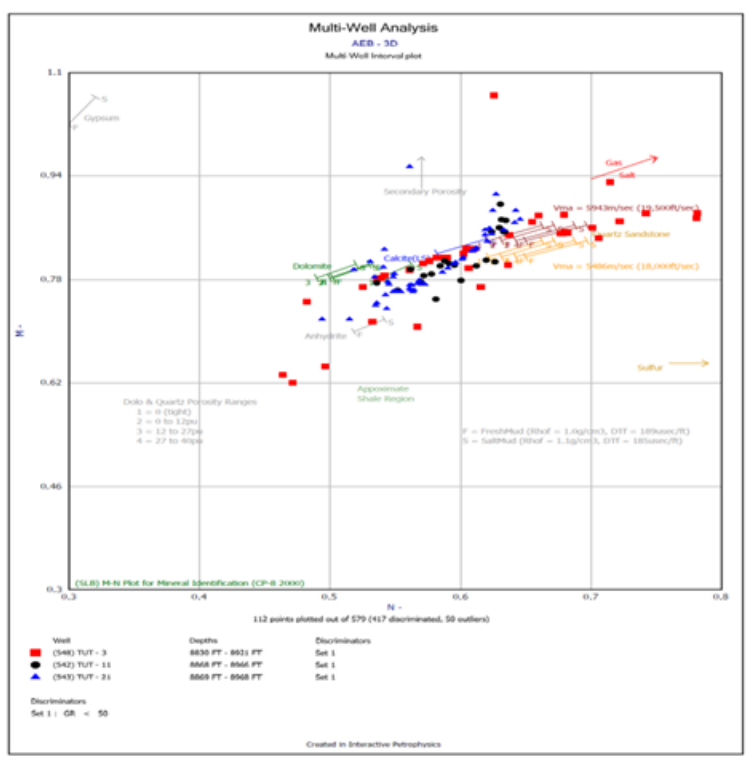

Fig.7: $\mathrm{M}$ - N crossplot of the AEB-3D reservoir.

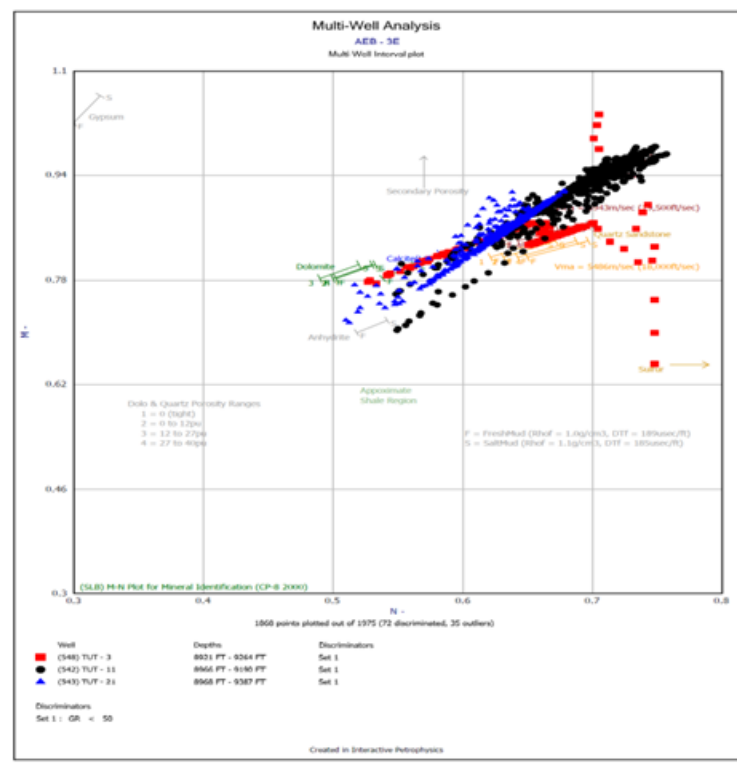

Fig.8: $\mathrm{M}$ - N crossplot of the AEB-3E reservoir.
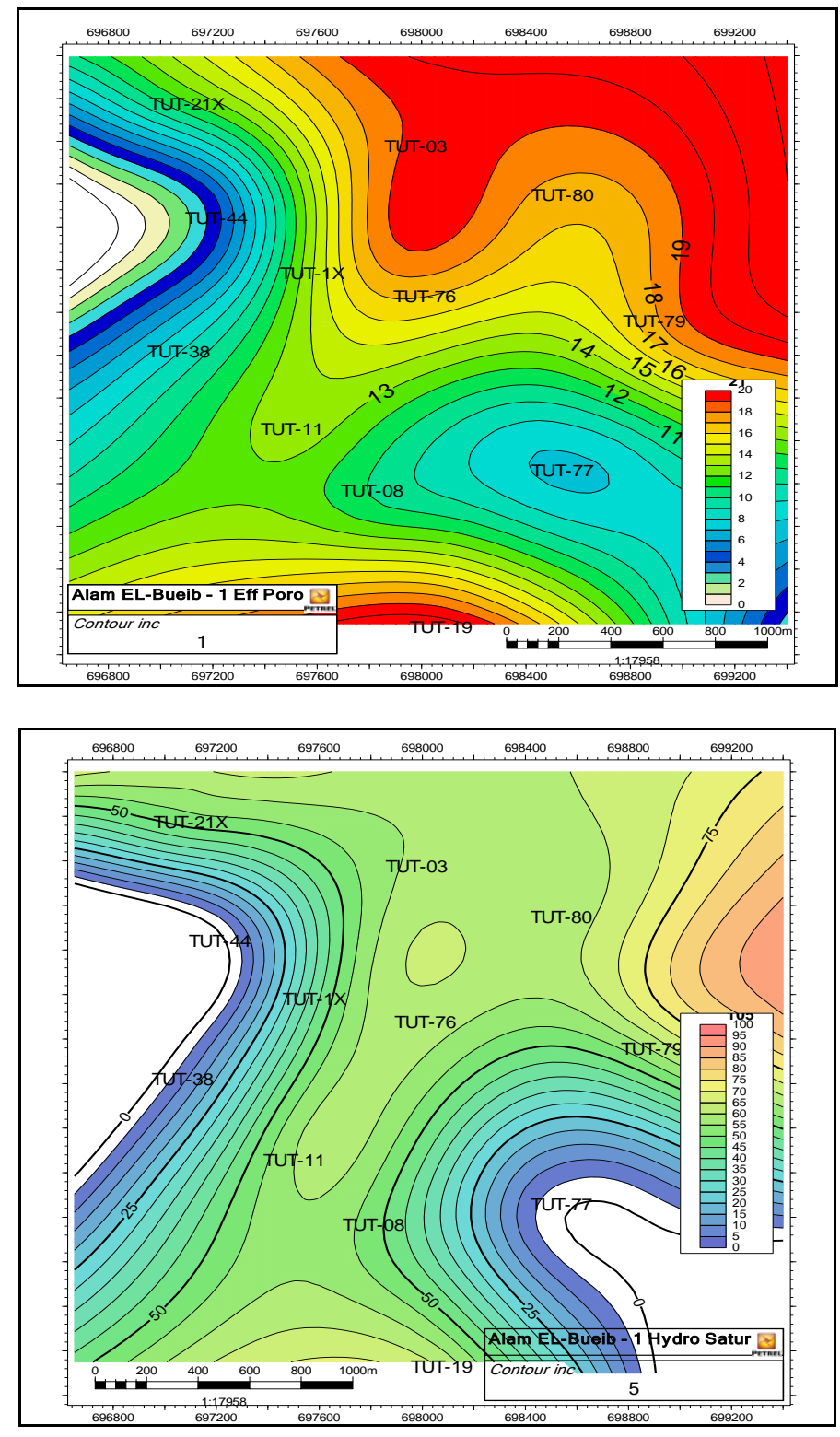


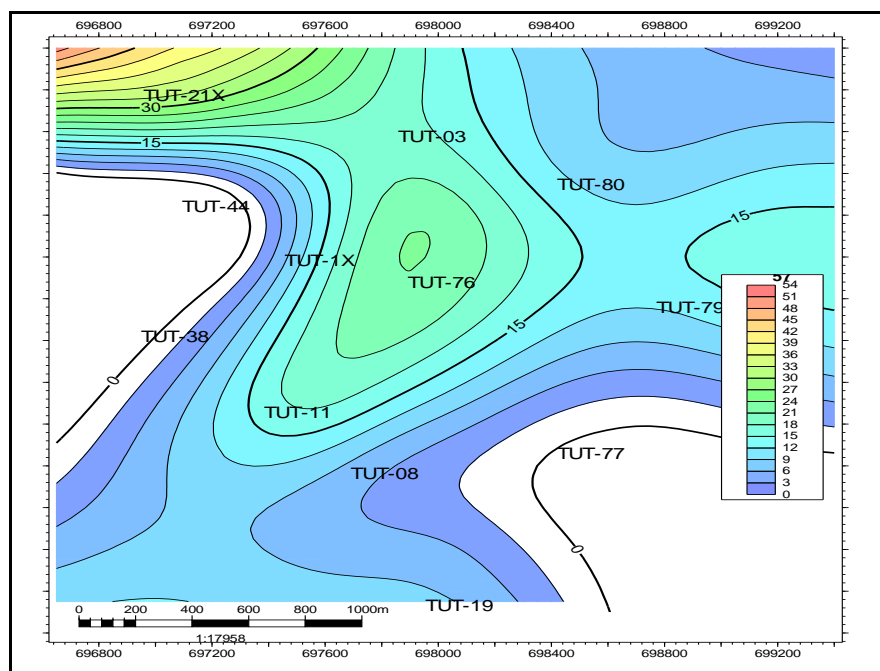

Fig. 9: (a) Effective Porosity, (b) Hydrocarbon Saturation and (c) Net Growth Sand in AEB-1 reservoir.
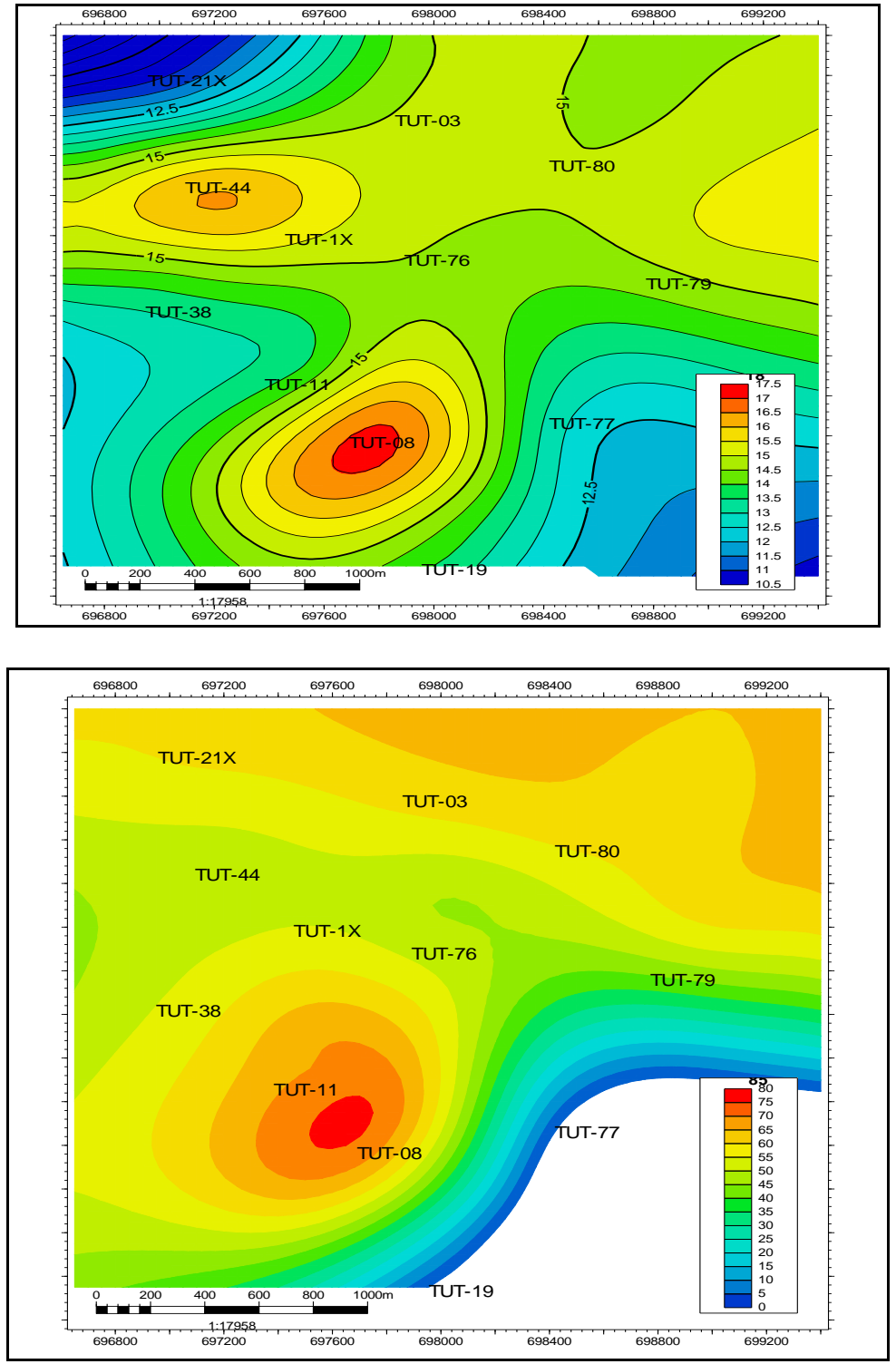


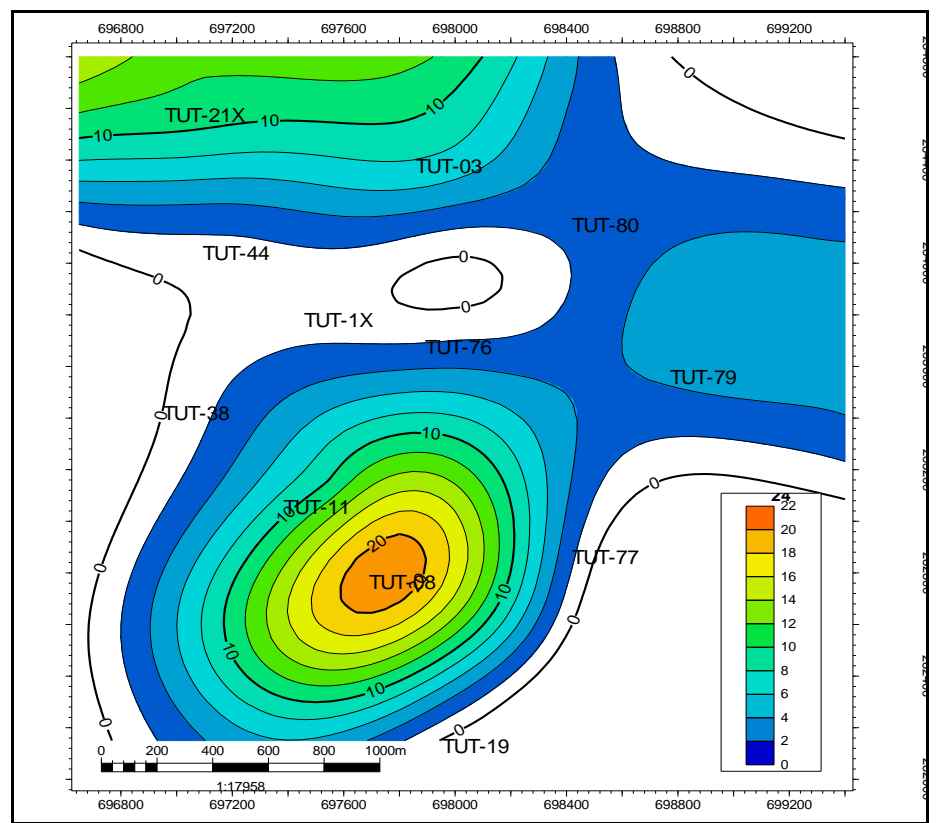

Fig. 10: (a) Effective Porosity, (b) Hydrocarbon Saturation and (c) Net Growth Sand in AEB-3A reservoir.
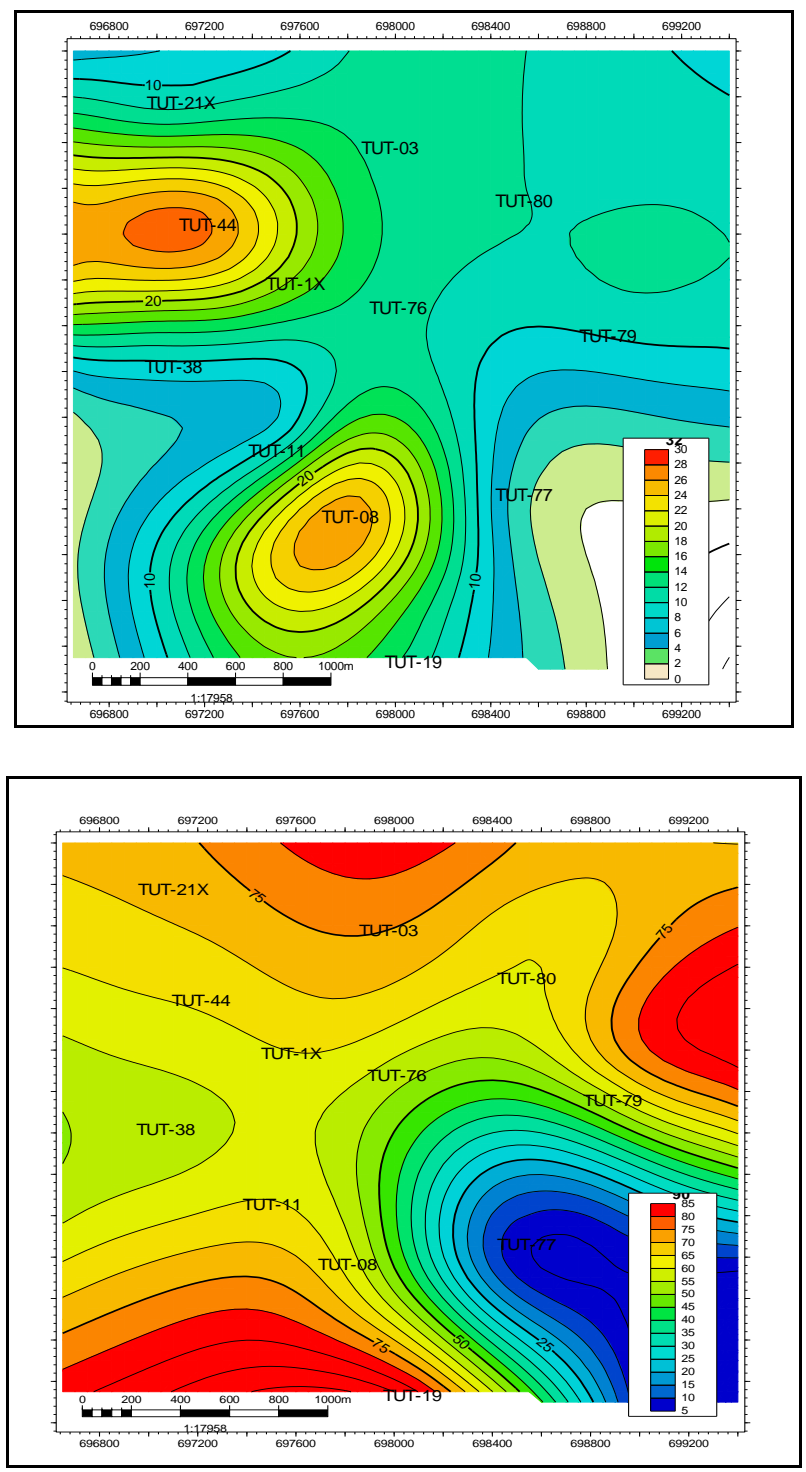


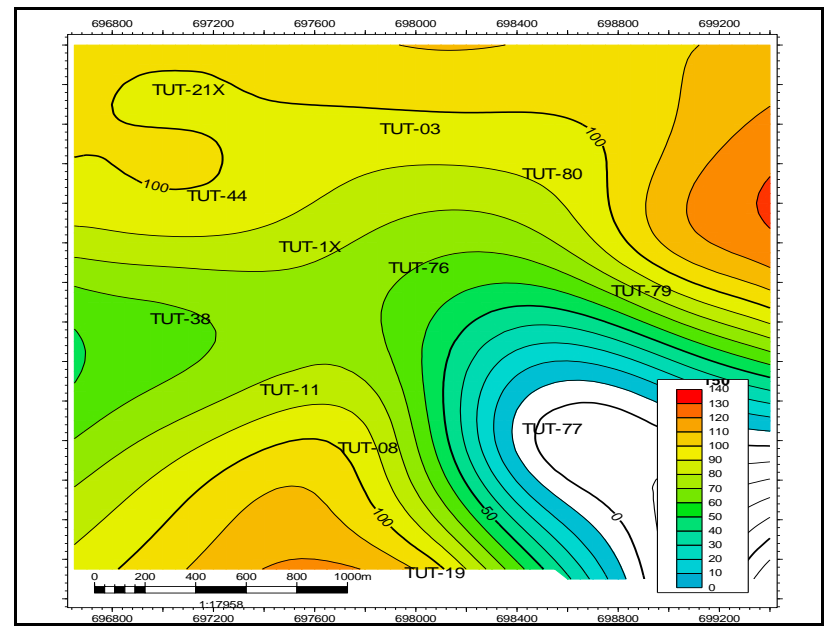

Fig. 11: (a) Effective Porosity, (b) Hydrocarbon Saturation and (c) Net Growth Sand in AEB-3D reservoir.
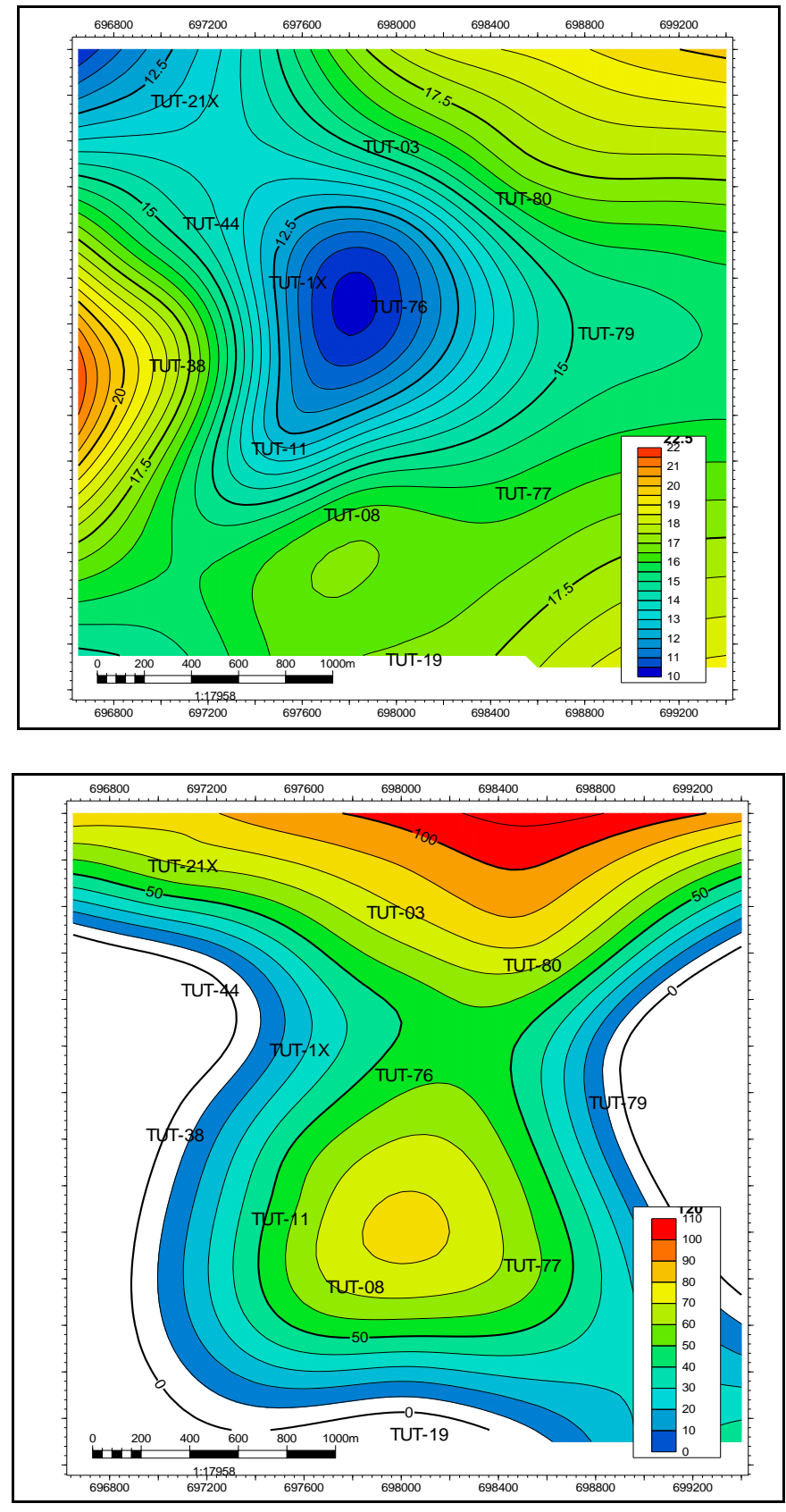


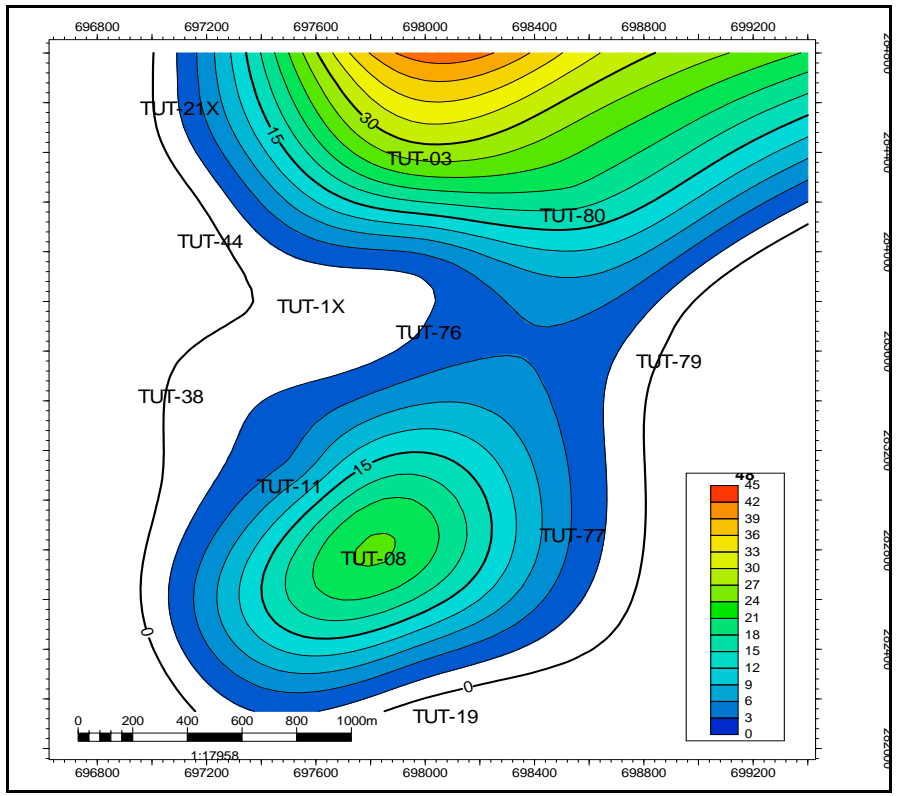

Fig. 12: (a) Effective Porosity, (b) Hydrocarbon Saturation and (c) Net Growth Sand in AEB-3E reservoir.

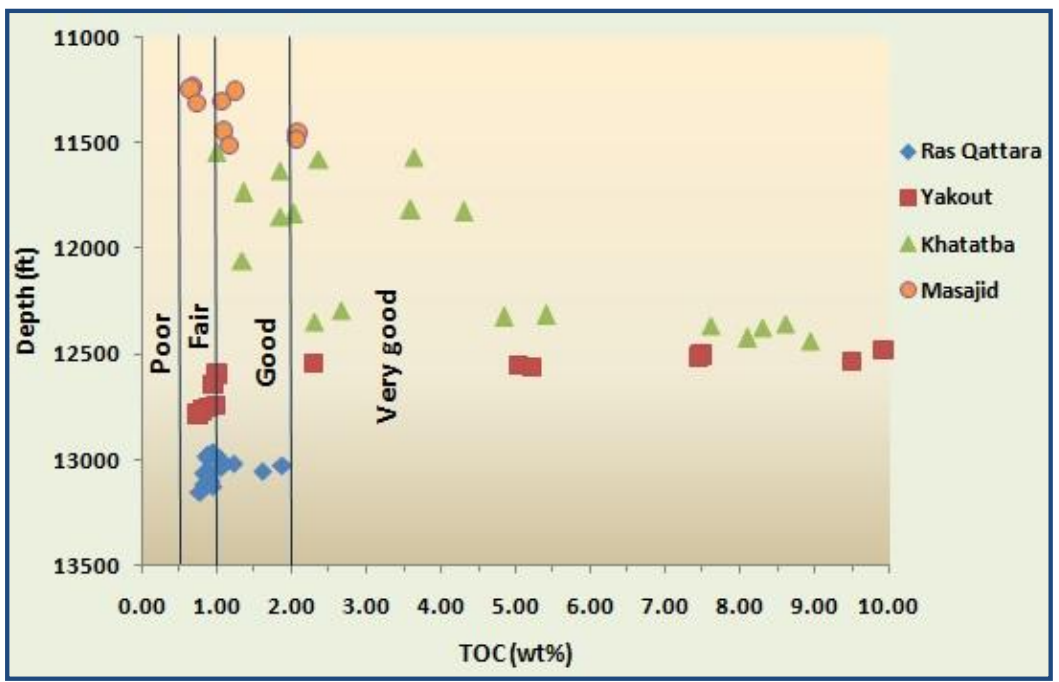

Fig. 13: Organic richness of Jurassic source rocks [23].

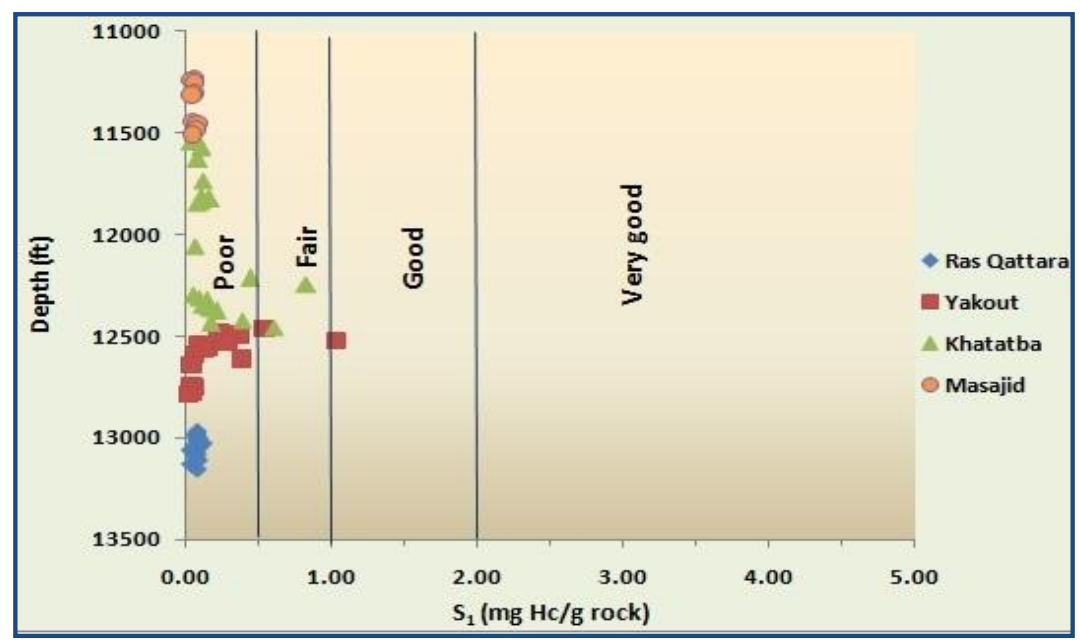

Fig.14: Hydrocarbons potentiality by S1 values of Jurassic source rocks. 


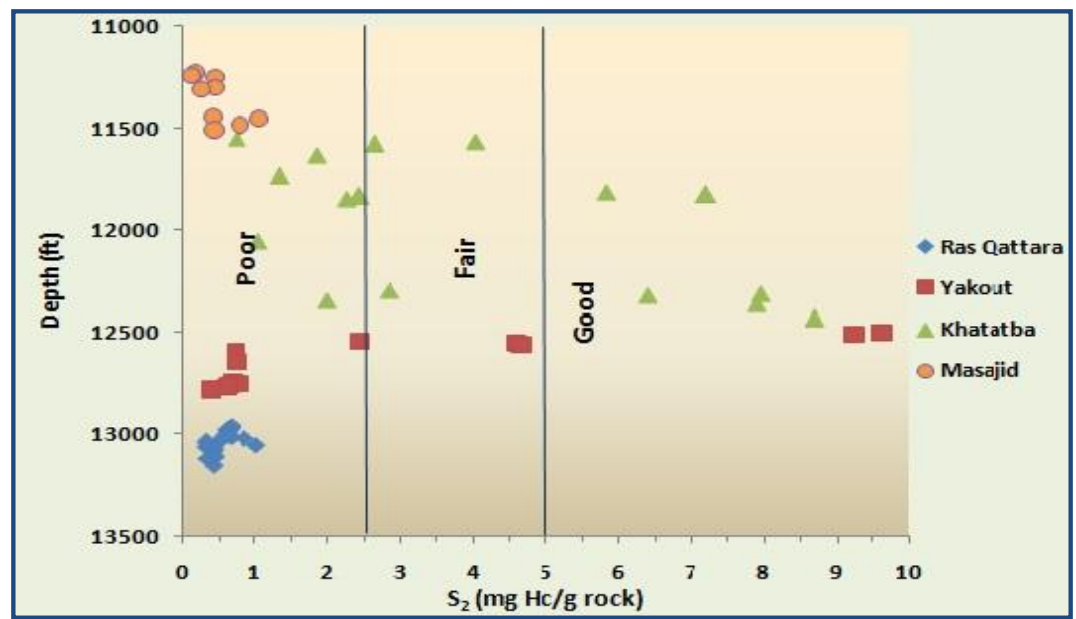

Fig.15: Hydrocarbons potentiality by S2 values of Jurassic source rocks.

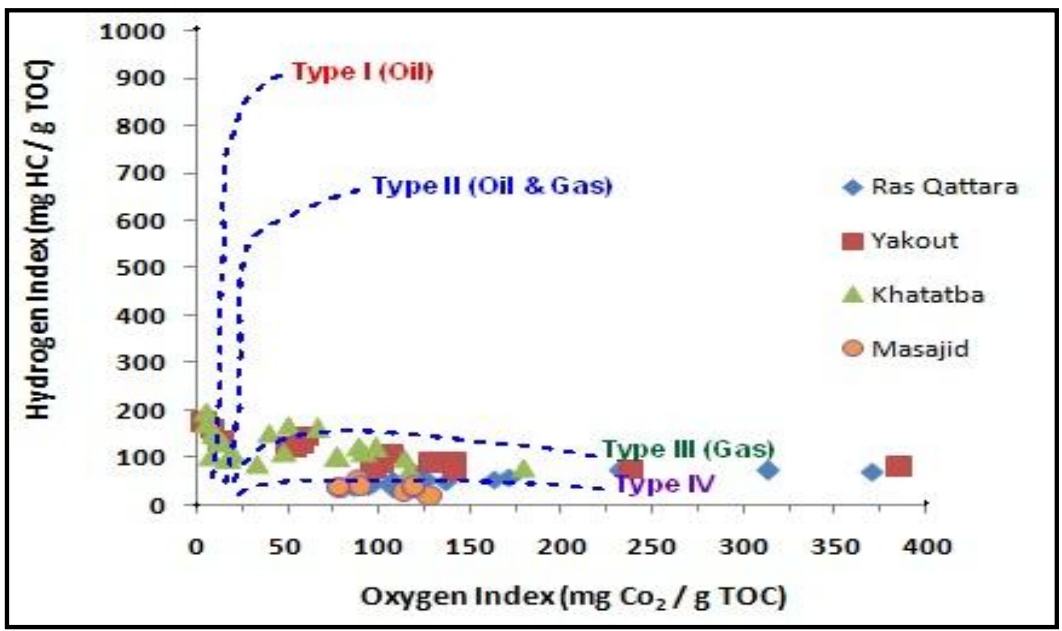

Fig.16: Hydrogen index versus Oxygen index for Jurassic formations [37\&38].

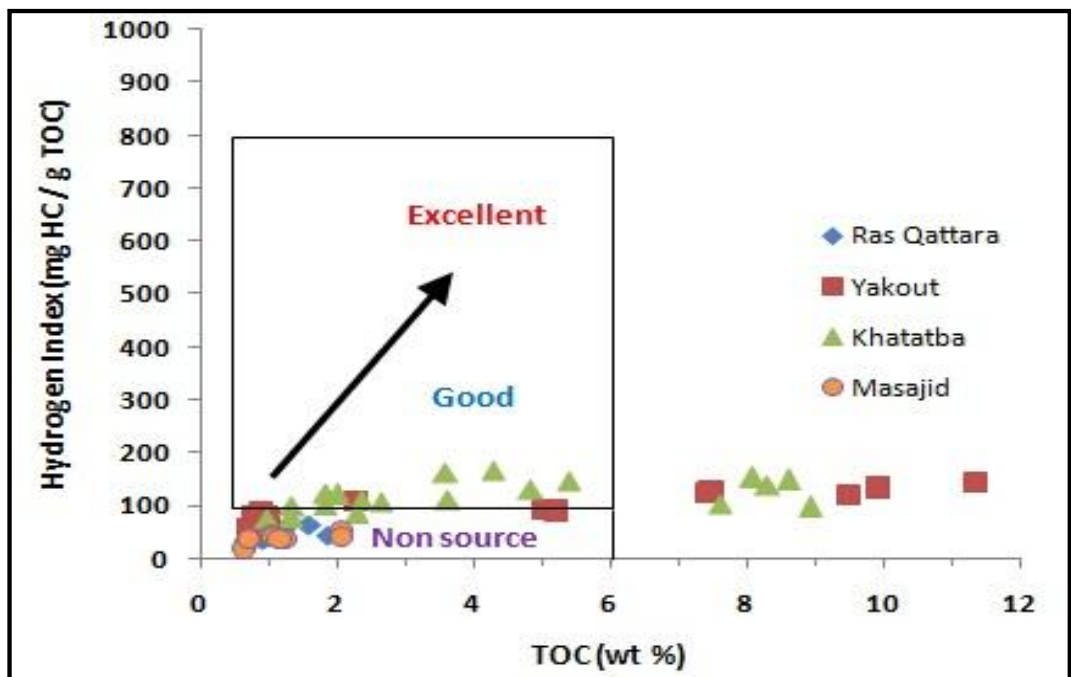

Fig.17: Total organic carbon versus hydrogen index of Jurassic source rocks [26]. 


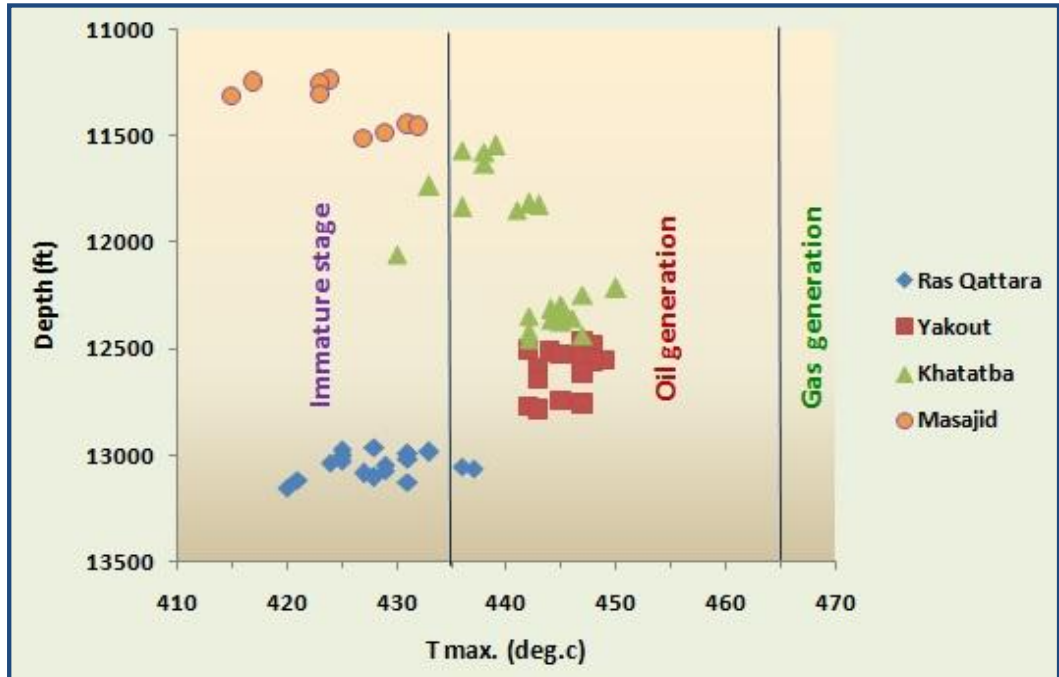

Fig.18: Thermal maturity of Jurassic source rocks by $\mathrm{T}_{\max }[23]$.

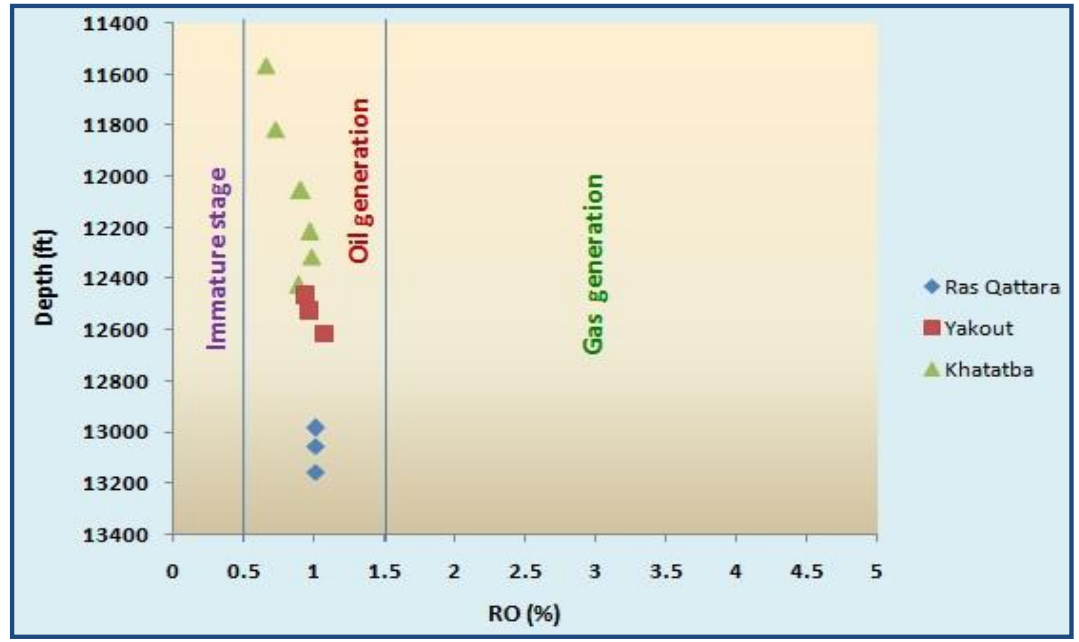

Fig.19: Thermal maturity of Jurassic source rocks by Ro \% [23].

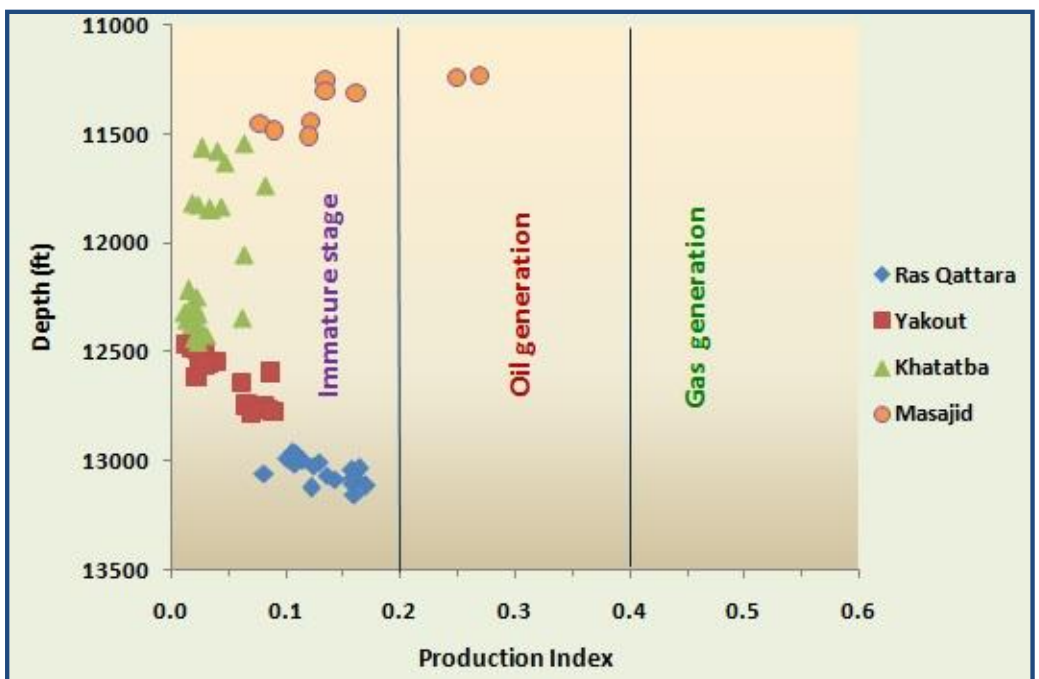

Fig.20: Thermal maturity of Jurassic source rocks by production index [23]. 


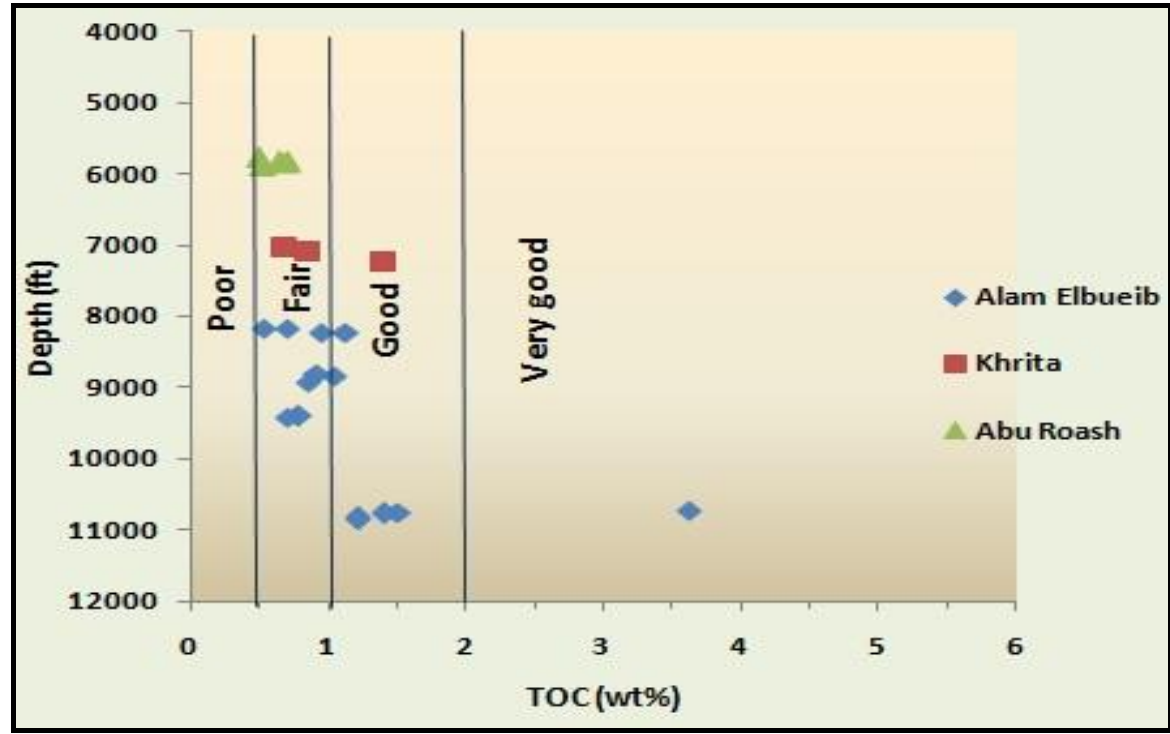

Fig.21: Organic richness of Cretaceous source rocks [23].

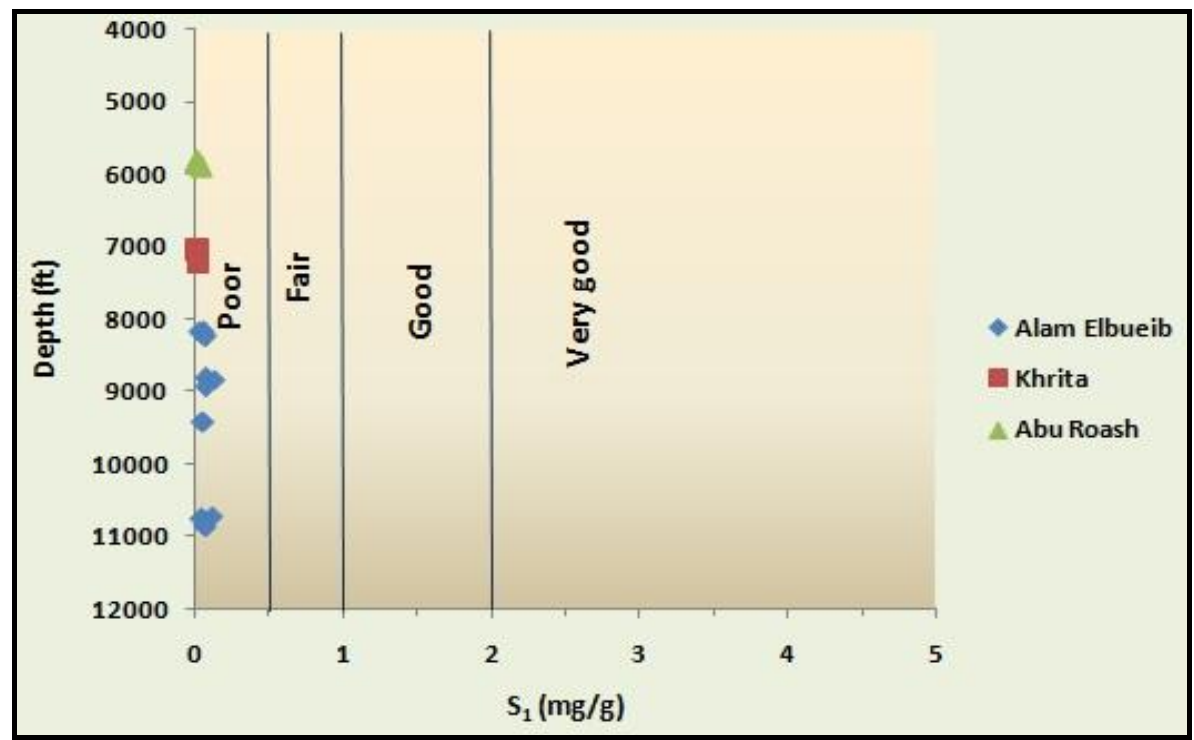

Fig.22: Hydrocarbons potentiality by $\mathrm{S} 1$ values of Cretaceous source rocks.

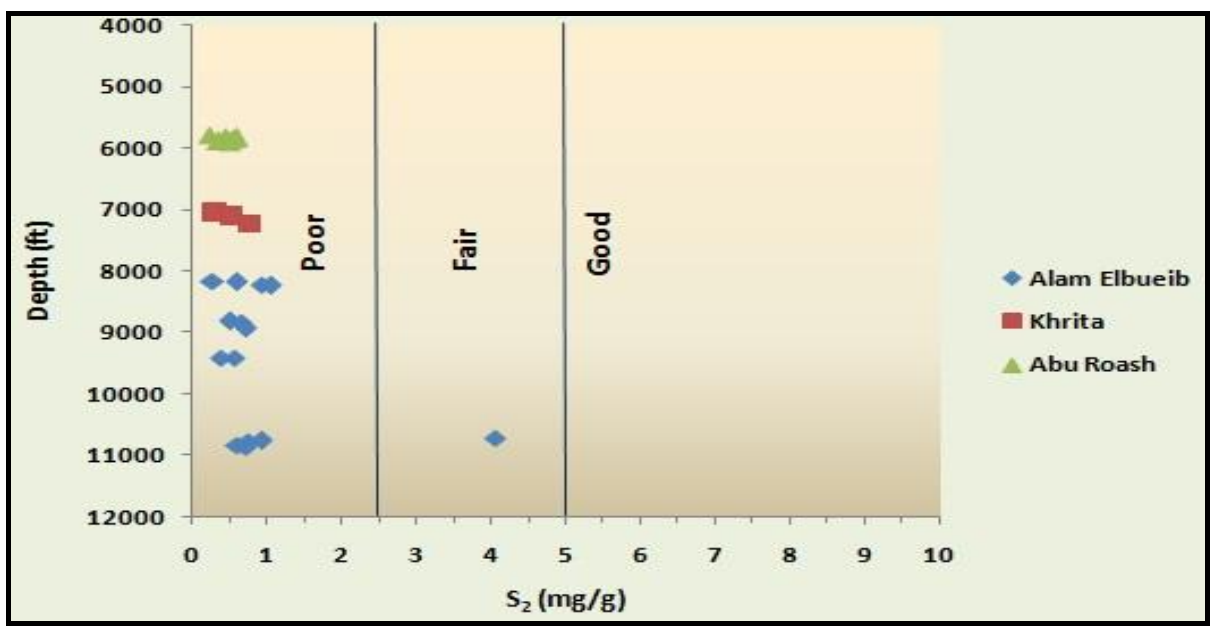

Fig.23: Hydrocarbons potentiality by $\mathrm{S} 2$ values of Cretaceous source rocks. 


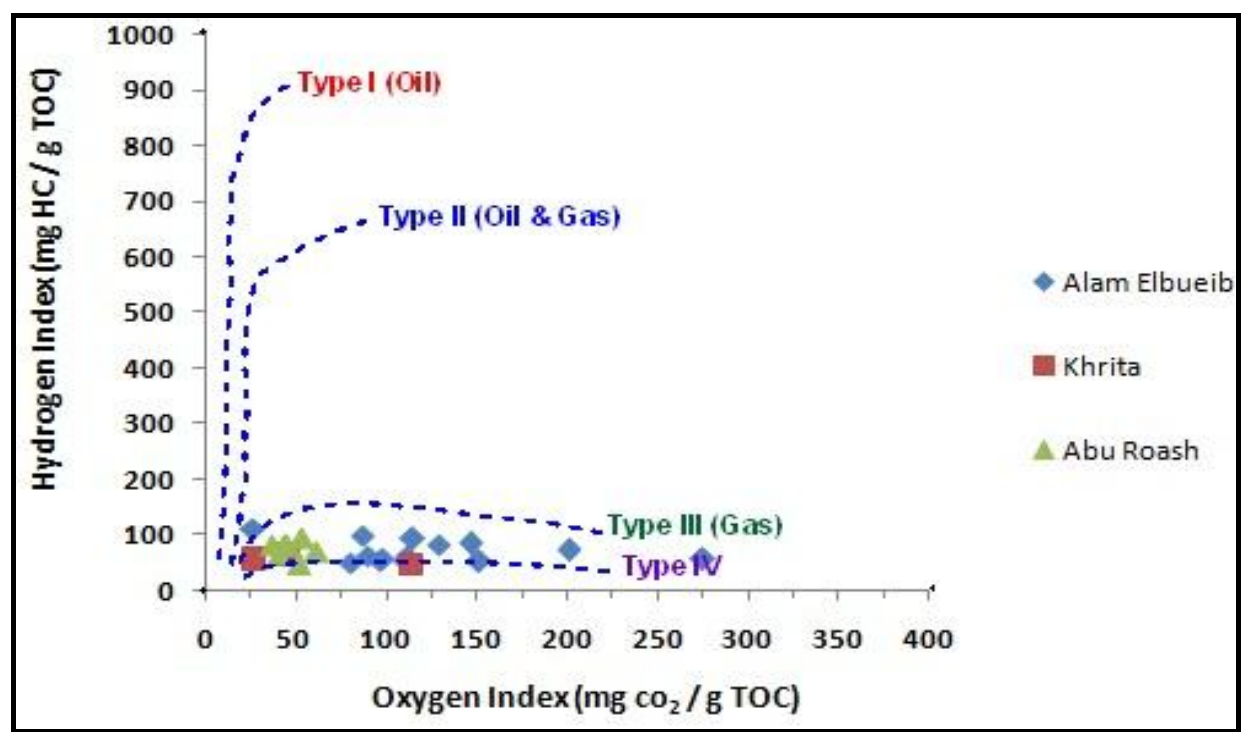

Fig.24: Hydrogen index versus Oxygen index for Cretaceous formations [37\&38].

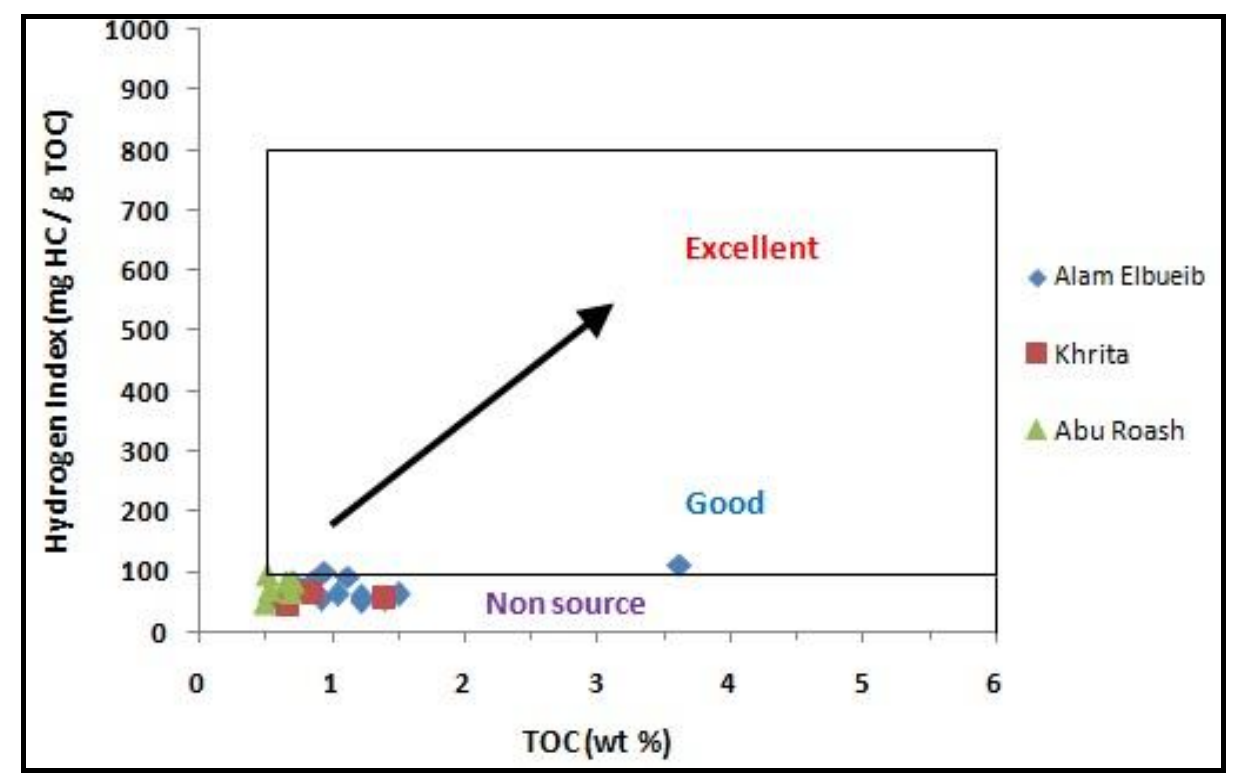

Fig.25: Total organic carbon versus hydrogen index of Cretaceous source rocks [26].

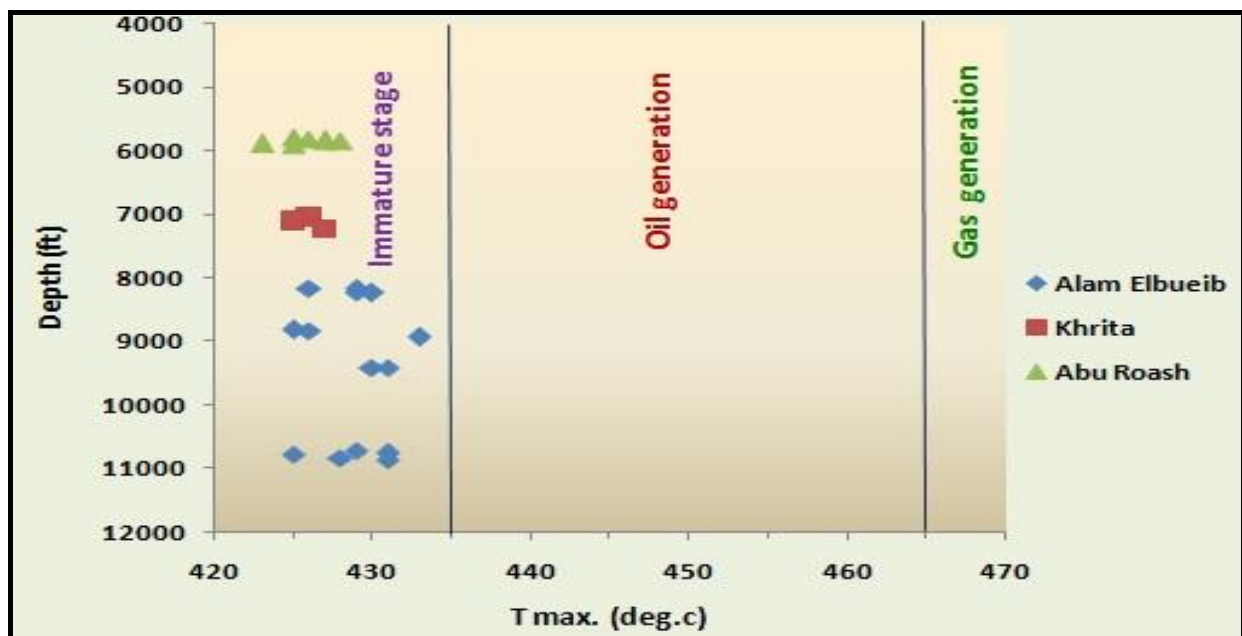

Fig.26: Thermal maturity of Cretaceous source rocks by $\mathrm{T}_{\max }$ [23]. 


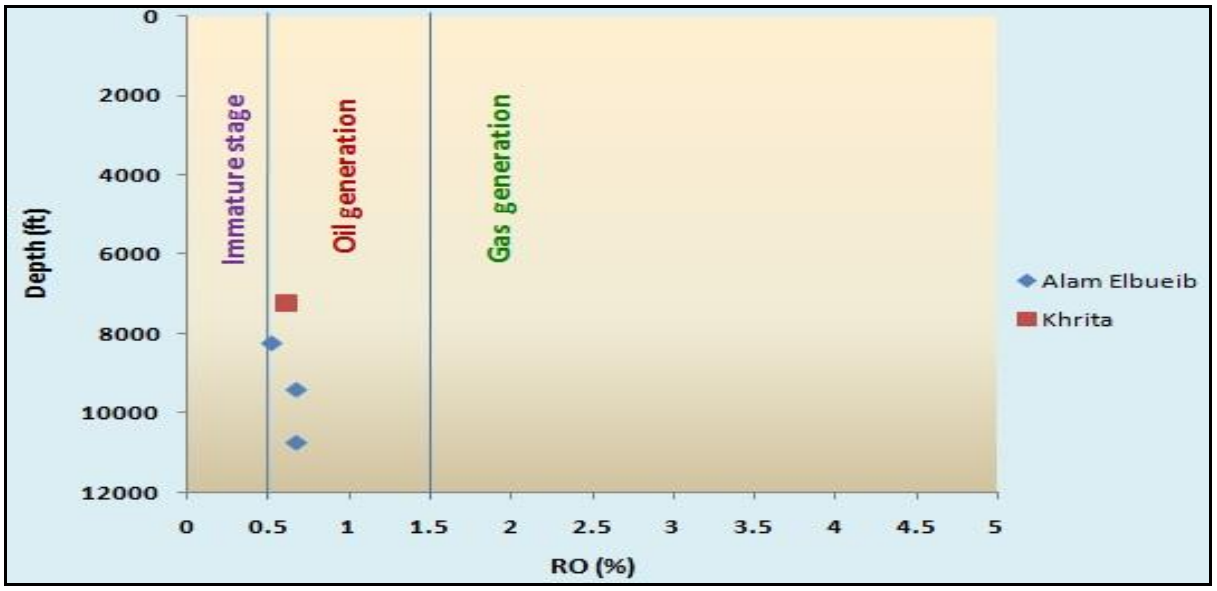

Fig.27: Thermal maturity of Cretaceous source rocks by Ro \% [23].

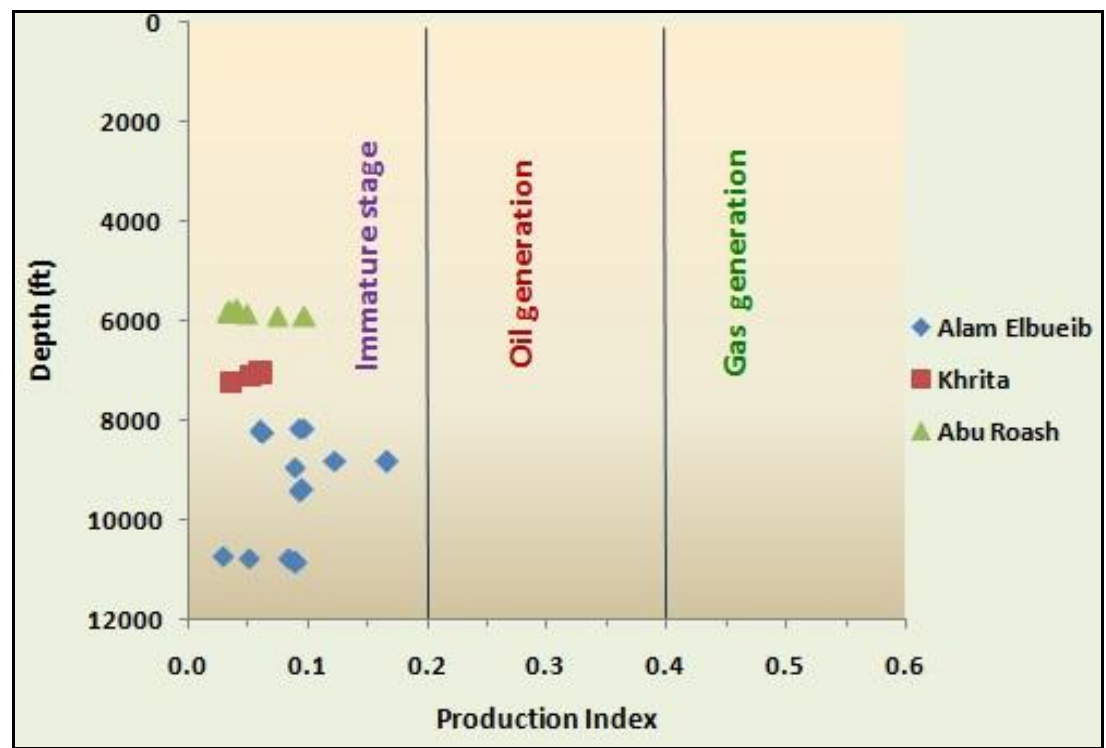

Fig.28: Thermal maturity of Cretaceous source rocks by production index [23]

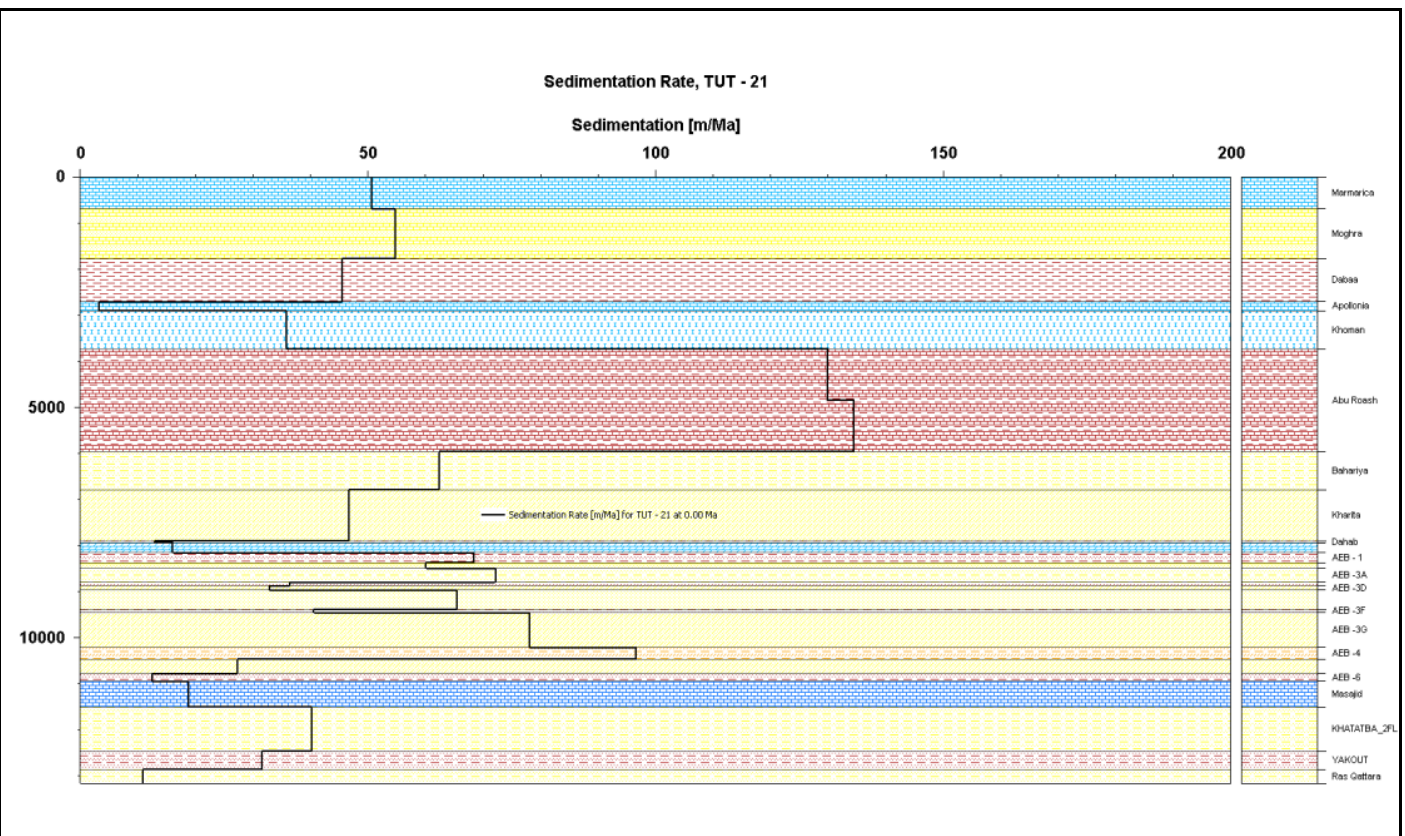

Fig.29: Sedimentation rate in TUT-21 well. 


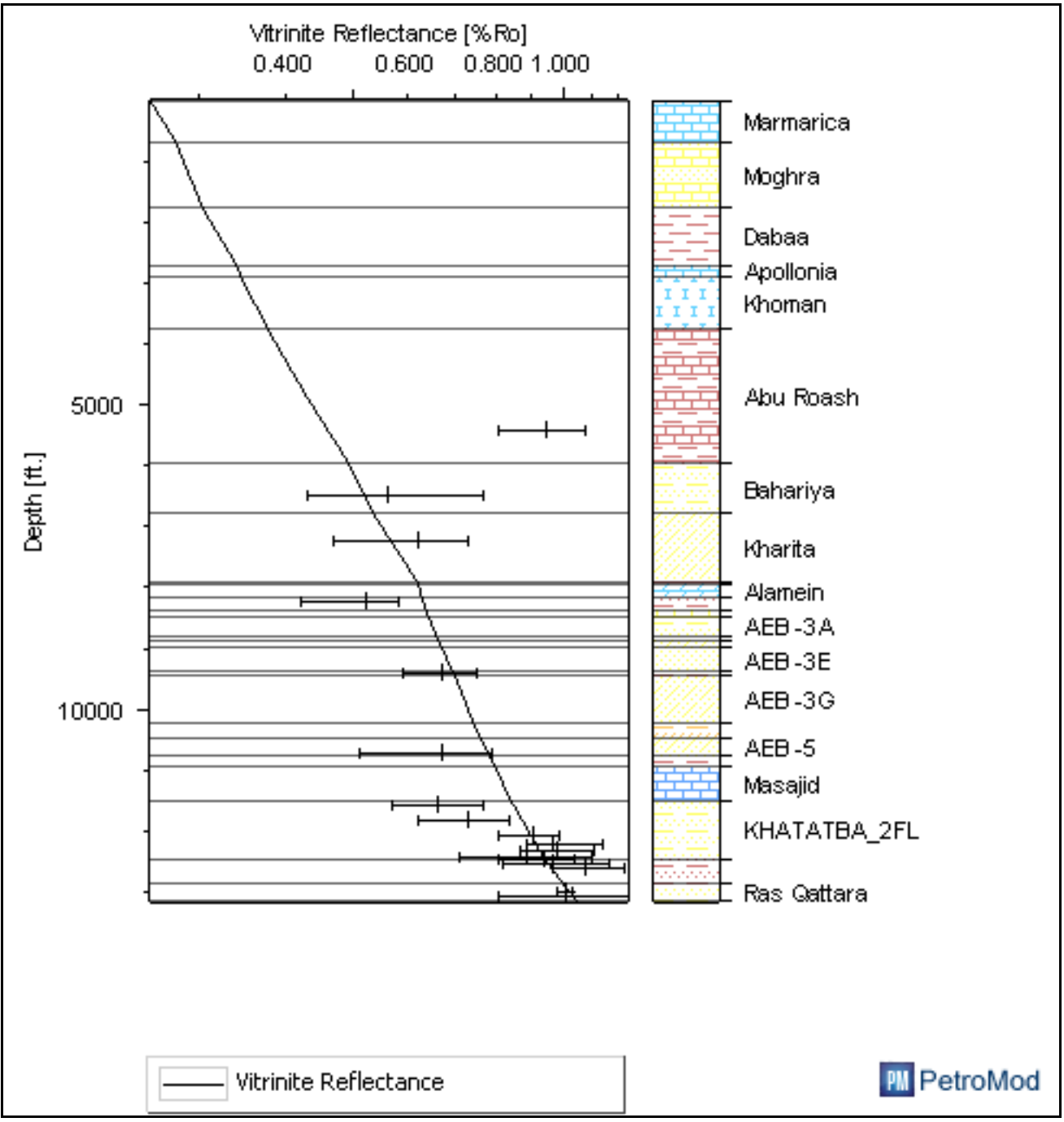

Fig.30: Plots of calculated (lines) and measured (symbols) vitrinite reflectance values and corrected borehole temperatures versus depth for studied wells.

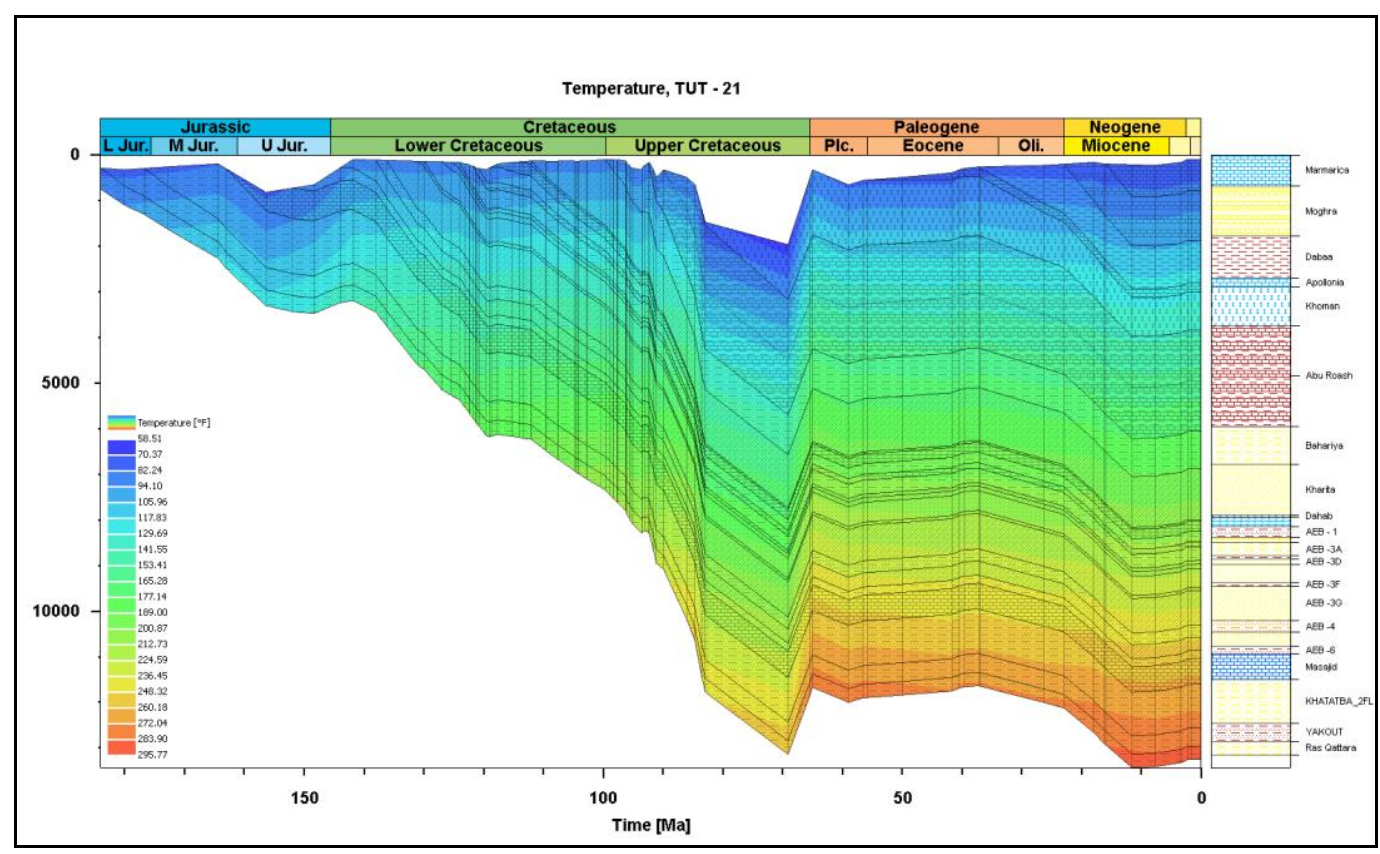

Fig.31: Burial history curves with palaeo-temperature zones in TUT-21 well, TUT Oil field, Shushan Basin. 


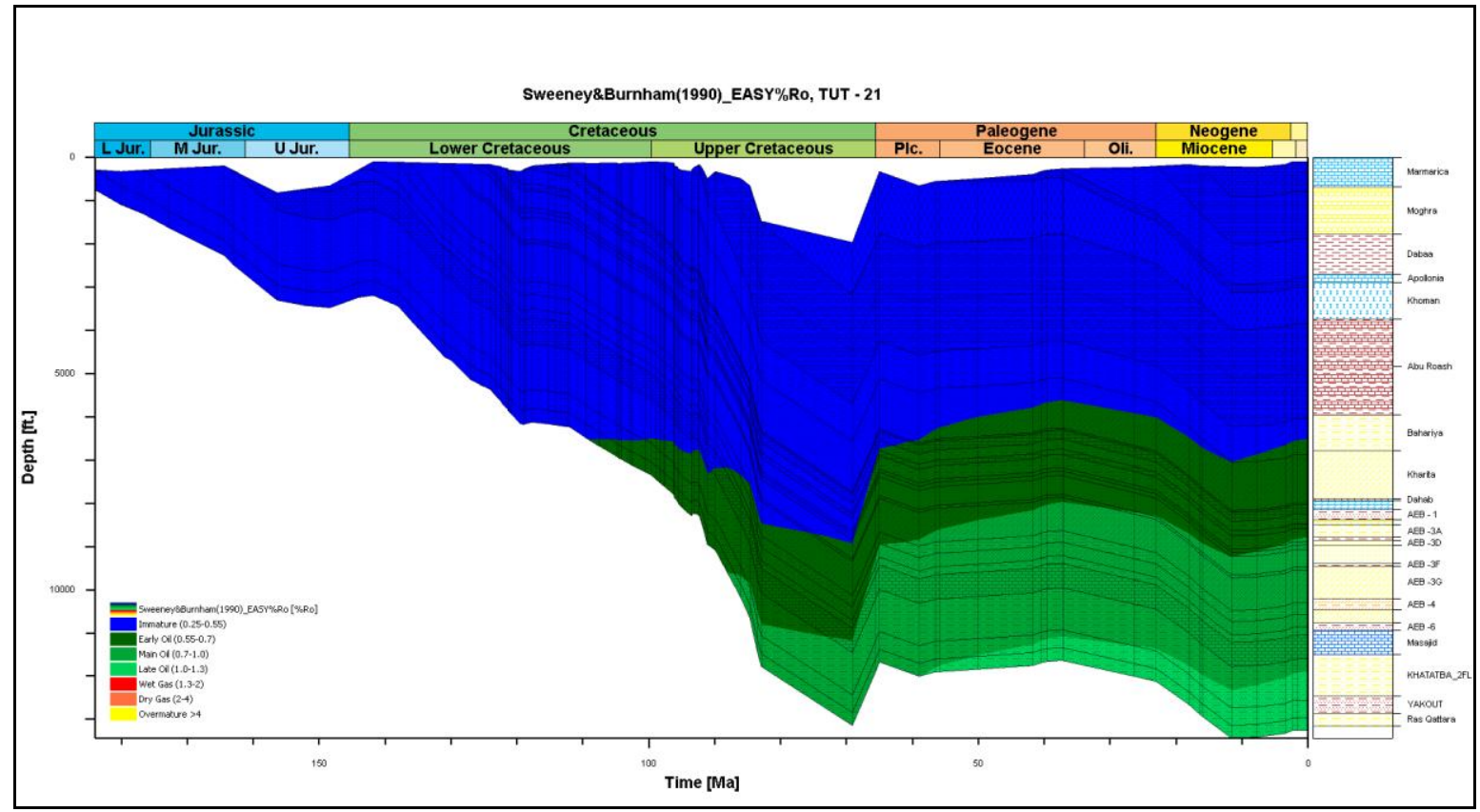

Fig.32: The burial history and hydrocarbon zones in TUT-21 well.

\section{Conclusions}

1. The analyzed of petrophysical parameters indicate that out of four units of the Alam EL-Bueib Formation in TUT Oil field, the AEB-1, AEB-3A, AEB-3D and AEB-3E are hydrocarbon-bearing. Formation show the presence of sandstone with some calcareous cement and the effective porosity mean value is $15.3 \%$ in AEB-1, $13.8 \%$ in AEB-3A, $10.7 \%$ in AEB-3D and $14.3 \%$ in AEB-3E.

2. The lithostratigraphic correlation chart illustrated that Alam EL-Bueib-1, 3A, 3D and 3E horizons were formed in the same depositional condition.

3. The vitrinite reflectance profiles show a general increase in vitrinite reflectance with depth and indicate that most units have attained sufficient burial depth and thermal maturity for significant hydrocarbon generation. The temperature values increase systematically with depth and reached maximum temperatures at Neogene time.

4. Ras Qattara and Masajid formations have poor to fair generation potential while, Yakout and Khatatba formations have poor to excellent generation potential. Vitrinite reflectance values indicate that Ras Qatara, Yakout and Khatatba formations source rocks are mature and lie within oil generation stage.

5. The organic richness of the Cretaceous formations varies from poor to excellent. The Cretaceous source rocks contain type IV kerogen and it indicates that the Cretaceous formations have very little gas potential and will not yield oil in any maturation stage. Vitrinite reflectance values indicate that Alam El Bueib and Kharita source rocks are becoming mature and lie within the onset of the oil generation stage.

6. The burial history modeling shows that Ras Qattara and Yakout formations lie within the main mature oil window. Khataba and Masajid formations lie within oil windows and Alam El-Bueib and Khrita Formations are still within the early stage of hydrocarbon generation. While the Abu Roash Formation lie within immature stage.

7. In summary, results from the present study reveal that the hydrocarbon exploration processes should be focused on the Khatatba, Yakout and Ras Qattara formations for predicting the source kitchen.

8. The Jurassic-Cretaceous formations are important oil and gas source rocks in the Tut oilfield, Shoushan Basin, Western Desert, Egypt.

\section{References}

[1]. El Ayouty, M.K., 1990. Petroleum geology. In: Said, R. (Ed.), The Geology of Egypt. A.A. Balkema, Rotterdam, pp. 567-599.

[2]. Alsharhan, A.S., Abd El-Gawad, E.A., 2008. Geochemical characterization of potential Jurassic/Cretaceous source rocks in the Shushan Basin, north Western Desert, Egypt. J. Pet. Geol. 31:191-212.

[3]. Dahi, M., and Shahin, A.N., 1992. Paleozoic rocks distribution and hydrocarbon potential in the Western Desert, Egypt. Paper presented at the 11th Petroleum Exploration and Development Conference, Cairo.

[4]. Khaled, K.A., 1999. Cretaceous source rocks at Abu Gharadig oil and gas field, north Western Desert, Egypt. J. Pet. Geol. 22:377395

[5]. Sharaf, L.M., 2003. Source rock evaluation and geochemistry of condensates and natural gases, offshore Nile Delta, Egypt. J. Pet. Geol 26:189-209 
Petrophysical Evaluation and Potential Capability of Hydrocarbon Generation of Jurassic and ..

[6]. Shalaby, M.R., Hakimi, M.H., Abdullah, W.H., 2011. Geochemical characteristics and hydrocarbon generation modelling of the Jurassic source rocks in the Shoushan Basin, north Western Desert, Egypt. Mar. Pet. Geol. 28:1611-1624

[7]. El Nady, M.M., and Hakimi, M. H., 2016. The petroleum generation modeling of prospective Jurassic-Cretaceous source rocks in Tut Oilfield, North Western Desert, Egypt: An integrated bulk pyrolysis and 1D- basin modeling. J. Arabian Geosci. 9:1-14.

[8]. El Nady, M. M., 2015. Evaluation of the nature, origin and potentiality of the subsurface Middle Jurassic and Lower Cretaceous source rocks in Meleiha G-1x well, North Western Desert, Egypt. Egypt. J. Pet. 24 (3):317-323.

[9]. El Shazly, E.M., 1977. The geology of the Egyptian region. In: Stehli FG (ed) The ocean basins and margins, Kanes, A.E.M., F.G. Plenum, New York, pp. 379-444

[10]. Mesherf, W.M/, Abdel Bki, S.H., AbdelHady, H.M., and Soliman S.A., 1980. Magnetic trend analysis in the northern part of Arabian-Nubian Shied and its tectonic in plications. Annu. Geol. Surv. Egypt 10: 939-953

[11]. Barakat, M.G., Darwish, M., and Abdelhamid, M.L., 1987. Hydrocarbon source rock evaluation of the upper Cretaceous (Abu Roash formation) East Abu Gharadig area, north Western Desert, Egypt. Ain Shams University, Earth Science Journal 1:120-150

[12]. Hantar, G., 1990. North Western Desert. In: Said R. (ed) The geology of Egypt. Balkema, Rotterdam, pp. 293-319.

[13]. Kerdany, M. T., Cherif, O. H., 1990. Mesozoic. In: Said R. (ed) The geology of Egypt. Balkema, Rotterdam, pp. 407-438.

[14]. Zein El-din, M.Y., Abd El-Gawad, E.A., El-Shayb, H.M., Haddad, I.A., 2001. Geological studies and hydrocarbon potentialities of the Mesozoic rocks in Ras Kanayis onshore area, north Western Desert. Egypt Annals of the Geological Survey of Egypt XXIV: $115-134$.

[15]. Abdou, A.A., Shehata, M.G., Kassab, M.A.M., 2009. Petrography and probable reservoir potentiality of subsurface Jurassic rocks at Abu Gharadiq Basin and Shoushan Sub-basin, north Western Desert, Egypt. Aust. J. Basic Appl. Sci. 3:1206-1222.

[16]. El-khadragy, A. A., Saad, M. H., and Azab, A., 2010. Crustal modeling of south Sitra area, north Western Desert, Egypt using Bouguer gravity data. J. Appl. Sci. Res. 61:22-27.

[17]. Said, R. (1962): The Geology of Egypt - 377 pp., Elsevier, New York.

[18]. [Sultan, N., and Abdelhalim, M. A., 1988. Tectonic framework of Northern Western Desert, Egypt and its effect on hydrocarbon accumulations. EGPC 9th, Cairo. p. 1-23 volume II.

[19]. Sweeney, J.J., Burnham, A.K., 1990. Evaluation of a simple model of vitrinite reflectance based on chemical kinetics. AAPG Bulletin 74, 1559-1570.

[20]. Bruke, J.A., Campbell, R.L. and Schmidt, A.W., 1969. The litho-porosity crossplot. The log analyst (SPWLA), 10 (6).

[21]. Waples, D.W., 1985. Geochemistry in petroleum exploration. International Human Resources Development Corporation, Boston, $232 \mathrm{p}$.

[22]. Hunt, J.H., 1996. Petroleum geochemistry and geology. 2nd. ed., Freeman and Comapny, New York, 743 p.

[23]. Peters, K.E., 1986. Guidelines for evaluating petroleum source rock using programmed pyrolysis. AAPG Bull., 70: 318-329.

[24]. Peters, K.E., Cassa, M.R., 1994. Applied Source Rock Geochemistry. In: Magoon, L.B., Dow, W.G. (Eds.), The Petroleum System - From Source to Trap: American Association of Petroleum Geologists Memoir, 60, pp. 93-120.

[25]. Ghori, K.A.R. and Haines, P.W., 2007. Paleozoic petroleum systems of the canning basin, Western Australia: Search and Discovery Article No.10120.

[26]. Mann, U. J., Knies, S. Chand, W. Jokat, R. Stein and J. Zweigel, 2009. Evaluation and modeling of Tertiary source rocks in the central Arctic Ocean, Marine and Petroleum Geology, 26: 1624-1639.

[27]. Lopatin, N.V., 1971. Temperature and geologic time as factors in coalification. Izv Akad. Nauk. SSSR. Ser. Geol. 3:95-106.

[28]. Welte, D.H., Yukler, A., 1981. Petroleum origin and accumulation in basin evolution-a quantitative model. AAPG Bull. 65:13871396.

[29]. Hermanrud, C., 1993. Basin modelling techniques-an overview. In: Dore AG, Augustson, J.H., Hermanrud, C., Stewart, and D.J., Sylta, O., (eds) Basin modelling: advances and applications. Norwegian Petroleum Society (NPF) Special Publication, pp. 1-34.

[30]. Yalcin, M.N., Littke, R., Sachsenhofer, R.F., 1997. Thermal history of sedimentary basins. In: Welte, D.H., Horsfield, B., and Baker, D., (eds.) Petroleum and basin evaluation. Springer, Berlin, pp. 73-167.

[31]. Lachenbruch, A., 1970. Crustal temperature and heat productivity: implications of the linear heat flow relation. J. Geophys. Res. 75:3291-3300

[32]. Allen, P.A., and Allen J.R., 1990. Basin analysis principles and applications. Blackwell Scientific Publications, Oxford, pp. 1-642.

[33]. Shalaby, M.R., Hakimi, M.H., and Abdullah, W.H., 2012. Geochemical characterization of solid bitumen (migrabitumen) in the Jurassic sandstone reservoir of the Tut Field, Shushan Basin, northern Western Desert of Egypt. Int. J. Coal. Geol. 100:26-39.

[34]. Egyptian General Petroleum Corporation, 1992. Western Desert oil and gas fields, a comprehensive overview. - Paper presented at the 11th Petroleum Exploration and Production Conference, EGPC, Cairo. pp. 1-431.

[35]. Schlumberger, 1984. Geology of Egypt pp.1-64. - Paper presented at the Well Evaluation Conference, Schlumberger, Cairo.

[36]. Schlumberger, 1995. Geology of Egypt: 58-66. - Paper presented at the Well Evaluation Conference, Schlumberger, Cairo

[37]. Van Krevelen, D.W., 1961. Coal Typology Chemistry Physics Constitution, Elsevier Publishing Company.

[38]. Espitalie, J., M. Madec, B.P. Tissot, J.J. Mening and P. Leplate, 1977. Source rock characterization method for petroleum exploration. 9th Annual offshore Tech. Conf., OTC 2935, 3: 439-448. 